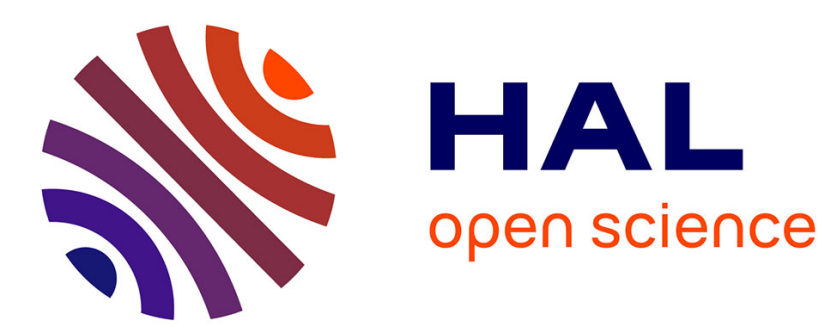

\title{
Regional-scale analysis of carbon and water cycles on managed grassland systems
}

Shaoxiu Ma, Romain Lardy, Anne-Isabelle Graux, Haythem Ben Touhami, Katja Klumpp, Raphaël Martin, Gianni Bellocchi

\section{To cite this version:}

Shaoxiu Ma, Romain Lardy, Anne-Isabelle Graux, Haythem Ben Touhami, Katja Klumpp, et al.. Regional-scale analysis of carbon and water cycles on managed grassland systems. Environmental Modelling and Software, 2015, 72, 10.1016/j.envsoft.2015.03.007 . hal-01210951

\section{HAL Id: hal-01210951 \\ https://hal.science/hal-01210951}

Submitted on 28 May 2020

HAL is a multi-disciplinary open access archive for the deposit and dissemination of scientific research documents, whether they are published or not. The documents may come from teaching and research institutions in France or abroad, or from public or private research centers.
L'archive ouverte pluridisciplinaire HAL, est destinée au dépôt et à la diffusion de documents scientifiques de niveau recherche, publiés ou non, émanant des établissements d'enseignement et de recherche français ou étrangers, des laboratoires publics ou privés. 
1

2

3

4
1 Regional-scale analysis of carbon and water cycles on

\section{2 managed grassland systems}

3

4

5

6 Shaoxiu $\mathrm{Ma}^{1}$, Romain Lardy ${ }^{2,3}$, Anne-Isabelle Graux ${ }^{4}$, Haythem Ben Touhami ${ }^{1}$, Katja

7 Klumpp ${ }^{1}$, Raphaël Martin ${ }^{1}$, Gianni Bellocchi ${ }^{1}$

8

9

$10{ }^{1}$ INRA, UR0874 Grassland Ecosystem Research, F-63039 Clermont-Ferrand, France

112 UMR 5505 IRIT, CNRS, University of Toulouse, France

$12{ }^{3}$ UMR 1248 AGIR, INRA-INPT, Castanet-Tolosan, France

134 INRA - Agrocampus Ouest, UMR 1348 PEGASE, Domaine de la Prise, 35590

14 Saint-Gilles, France 
Predicting regional and global carbon (C) and water dynamics on grasslands has

become of major interest, as grasslands are one of the most widespread vegetation types worldwide, providing a number of ecosystem services (such as forage production and $\mathrm{C}$ storage). The present study is a contribution to a regional-scale analysis of the $\mathrm{C}$ and water cycles on managed grasslands. The mechanistic biogeochemical model PaSim (Pasture Simulation model) was evaluated at 12 grassland sites in Europe. A new parameterization was obtained on a common set of eco-physiological parameters, which represented an improvement of previous parameterization schemes (essentially obtained via calibration at specific sites). We found that $\mathrm{C}$ and water fluxes estimated with the parameter set are in good agreement with observations. The model with the new parameters estimated that European grassland are a sink of $\mathrm{C}$ with $213 \mathrm{~g} \mathrm{C} \mathrm{m}^{-2} \mathrm{yr}^{-1}$, which is close to the observed net ecosystem exchange (NEE) flux of the studied sites (185 $\mathrm{g} \mathrm{C} \mathrm{m}^{-2} \mathrm{yr}^{-1}$ on average). The estimated yearly average gross primary productivity (GPP) and ecosystem respiration (RECO) for all of the study sites are 1220 and $1006 \mathrm{~g} \mathrm{C} \mathrm{m}^{-2} \mathrm{yr}^{-1}$, respectively, in agreement with observed average GPP (1230 $\left.\mathrm{g} \mathrm{C} \mathrm{m}^{-2} \mathrm{yr}^{-1}\right)$ and RECO (1046 $\left.\mathrm{g} \mathrm{C} \mathrm{m}^{-2} \mathrm{yr}^{-1}\right)$. For both variables aggregated on a weekly basis, the root mean square error (RMSE) was $~ 5-16 \mathrm{~g} \mathrm{C}$ week $^{-1}$ across the study sites, while the goodness of fit $\left(\mathrm{R}^{2}\right)$ was $\sim 0.4-0.9$. For evapotranspiration (ET), the average value of simulated ET (415 $\mathrm{mm} \mathrm{yr}^{-1}$ ) for all sites and years is close to the average value of the observed 
$\left.37 \mathrm{R}^{2}=0.3-0.9\right)$. However, further model development is needed to better represent soil water dynamics under dry conditions and soil temperature in winter. A quantification

39 of the uncertainties introduced by spatially generalized parameter values in $\mathrm{C}$ and

40 water exchange estimates is also necessary. In addition, some uncertainties in the

41 input management data call for the need to improve the quality of the observational

42 system.

43

44

45

46 Key word:

47 Carbon flux, eddy flux measurements, model evaluation, Pasture Simulation model

48

(PaSim), water balance 
50

51 Name of Software: Pasture Simulation model (PaSim)

52 Developer: INRA, UR0874 initiative; contact: Raphaël Martin

53 Contact Address: INRA, UR0874 Grassland Ecosystem Research, 63039

54 Clermont-Ferrand, France

55 Telephone: +33-4-73624872

56 E-mail: raphael.martin@clermont.inra.fr

57 Availability: On request to the authors

58 Cost: free for no-profit use

59 Program language: Fortran

60

61 


\section{Introduction}

63

64

65

66

67

68

69

70

Accurate quantification of ecosystem carbon (C) and water fluxes over regions, continents, or the globe is essential for understanding the feedbacks between the terrestrial biosphere and the atmosphere in the context of global change and climate policy-making (Xiao et al., 2012; Ciais et al., 2013). In the last decades, significant progresses have been made in quantifying regional to global $\mathrm{C}$ and water fluxes by using ecosystem modelling (Jung et al., 2007; Xiao et al., 2009), atmospheric inverse modelling (Butler et al., 2010) and upscaling of flux observations from eddy covariance towers (Jung et al., 2011). In particular, integrated environmental modelling (Laniak et al., 2013) provides effective tools for studying C and water cycles in agricultural and natural systems. Ecosystem models have been intensively developed and used to estimate $\mathrm{C}$ and water exchanges between the atmosphere and biosphere (Bondeau et al., 1999; Churkina et al., 1999; Huntzinger et al., 2012; Warszawski et al., 2014). They represent the key processes (such as plant photosynthesis, ecosystem respiration and evapotranspiration) and climatic and management drivers (e.g. grazing, cutting and fertilization) that regulate energy and matter exchanges. However, most of the modelling efforts have focussed on forests (Bondeau et al., 1999; Schaefer et al., 2012; Wu et al., 2012) and croplands ( Palosuo et al., 2011; Roetter et al., 2012; Wattenbach et al., 2010), while lesser attention was given to grasslands (Ciais et al., 2010).

Grasslands are a widespread vegetation type worldwide, covering nearly one-fifth of the world's land surface (24 million $\mathrm{km}^{2}$ ) (Suttie et al., 2005) and playing a significant 
role in the global C cycle (Scurlock and Hall, 1998; Ciais et al., 2010). At global scale, grasslands were estimated to be a net $\mathrm{C}$ sink of about 0.5 Pg C per year (Scurlock and Hall, 1998), but with high spatial heterogeneity and considerable uncertainty on the estimate of C exchange. Janssens et al. (2005) estimated that grasslands provide a C sink of $66 \pm 90 \mathrm{~g} \mathrm{C} \mathrm{m}^{-2} \mathrm{yr}^{-1}$ over Europe. From an extensive network of flux towers, Schulze et al. (2009) inferred a net C sink: net biome production (NBP) in European grasslands of $57 \pm 34 \mathrm{~g} \mathrm{C} \mathrm{m}^{-2} \mathrm{yr}^{-1}$. However, grassland ecosystems are the most uncertain components of the Europe-wide $\mathrm{C}$ balance in comparison to forests and croplands because only few data and grassland-specific models are available (Ciais et al., 2010). As a consequence, it is urgent to improve and evaluate grassland models based on recently-available eddy flux data.

Over the last decades, grassland models were developed with different research foci. CENTURY model was developed to simulate soil C, N, P, and S dynamics on a monthly time step (Parton, 1988), with an updated version (DayCent) working on a daily basis (Parton et al., 2007). The Grassland Ecosystem Model (GEM) (Chen et al., 1996) linked biochemical, biophysical and ecosystem processes in a hierarchical approach to simulate $\mathrm{C}$ and $\mathrm{N}$ cycles, with focus on natural grasslands. The LINGRA model (Schapendonk et al., 1998) has been extensively applied to simulate growth of grasses, including perennial ryegrass (Rodriguez et al., 1999) and timothy (van Oijen et al., 2005) under northern and western European conditions. The Hurley Pasture Model (Thornley, 1998) describes the fluxes of $\mathrm{C}, \mathrm{N}$ and water in a grazed soil-pasture-atmosphere system. DairyMod was designed to simulate not only 
biophysical, but also dairy management options (Johnson et al., 2008). Several integrated or whole farm system models were also available to simulate the biogeochemical processes and also include decision support system, such as Whole Farm Model (Bright et al., 2000), GP-FARM (Ascough et al., 2007), Integrated Farm System Model (http://www.ars.usda.gov/Main/docs.htm?docid=8519) and FASSET (Chirinda et al., 2011). An overview of the state of the art and the developments needed for process-based modelling of grazed agricultural systems were addressed by Snow et al. (2014).

Recently, attempts have also been made to introduce management options into global dynamic vegetation and crop models in order to extend functionalities for grasslands on regional and global scales. Biome and global dynamic vegetation models such as LPJmL (Bondeau et al., 2007), Biome-BGC (Hidy et al., 2012), ORCHIDEE (Krinner et al., 2005) and CARAIB (Warnant et al., 1994) were improved with mowing and grazing options. At the same time, widely used crop models, such as STICS (Brisson et al., 2003; Ruget et al., 2009), EPIC (Williams et al., 1989), CropSyst (Stöckle et al., 2003), DNDC ( Rafique et al., 2011; Wang et al., 2012), DSSAT (Giraldo et al., 1999) and the APSIM platform (Holzworth et al., 2014) have also been adapted to simulate grasslands. These efforts have made great contributions to the overall development of grassland models (yet with a different detail in representing processes). However, model evaluation was limited in scope to specific goals (e.g. not all grassland models simulate biogeochemical cycles). A detailed evaluation of model performance against observational flux data from a variety of grassland sites is therefore desirable. In 
128

129

130

131

132

133

134

135

136

137

138

139

140

141

142

143

144

145

146

147

148

149

particular, for a process-based model representing in detail the mechanisms driving the functioning of grassland systems, evaluation is needed with extended datasets, which include different grassland observational sites with a diversity of climatic, management and soil conditions.

The process-based biogeochemical Pasture Simulation model (PaSim) is the focus of this study. It was originally developed by Riedo et al. (1998), based on the Hurley Pasture Model (Thornley, 1998), to simulate managed grasslands (clover-ryegrass swards). PaSim includes both grazing and cutting management options and is able to simulate a variety of temperate grassland ecosystems. Over the last decade, the model has been continuously improved to simulate $\mathrm{C}$, water and $\mathrm{N}$ cycles. New approaches were integrated into the modelling structure to simulate, for instance, nitrous oxide $\left(\mathrm{N}_{2} \mathrm{O}\right)$ emissions from soils (Schmid et al., 2001a) and methane $\left(\mathrm{CH}_{4}\right)$ emissions from animals (Vuichard et al., 2007a) as well as the performances (i.e. milk and meat production) of grazing animals (Graux et al., 2011). The model has been used in the climate-change impact studies (Graux et al., 2013; Vital et al., 2013), including an assessment of the contribution of forage-based systems to the global warming (Graux et al., 2012) with focus on France. However, PaSim has only been evaluated against a few European grassland sites using short periods of observed C fluxes and biomass production data, and based on limited parameterization (Vuichard et al., 2007a; Calanca et al., 2007). A full documentation and an extended evaluation of the model over a large number of sites are required. 
2002 and eddy-covariance flux measurements were made on this network within the European projects of the $5^{\text {th }}, 6^{\text {th }}$ and $7^{\text {th }}$ framework programs, such as GREENGRASS (Soussana et al., 2007b), CARBOMONT (Bahn et al., 2008; Wohlfahrt et al., 2008), CarboEurope (Gilmanov et al., 2010) and CARBO-Extreme (Reichstein et al., 2013).

This dataset provides a good opportunity to evaluate grassland model performances because these sites cover a variety of grassland types with contrasting management practices and representing different climate conditions.

The present study assesses the ability of PaSim to reproduce $\mathrm{C}$ and water fluxes of a number of European long-term eddy flux measurement sites. To do so, three sets of eco-physiological vegetation parameters (i.e. from permanent grassland, sown grassland, and an adjusted set, which is the calibrated parameter values based on flux measurements data and their plausible ranges) were applied in order to test whether a common set of vegetation parameters is appropriate to represent model outputs at European scale (regardless of the possible physiological dissimilarities among grasslands species in different places in Europe). Model calibration was not applied separately to each observational site. This did not make it possible to explore the spatial variability of model parameters. Testing such a scenario appeared beyond the scope of this paper since it implied too strong a deviation from the initial hypothesis of this regional study. Rather, we calibrated the model simultaneously on all datasets to find parameter values that would be applicable at regional scale. Multi-site calibration can be characterized by lower uncertainty than site-specific calibration, because more data are involved in the calibration process (e.g. Minunno et al., 2014). 
172 The availability of a variety of detailed flux data from multiple sites offers the 173 possibility of a genuine multi-location calibration of the model, holding to the 174 assumption that a uniform calibration across sites is appropriate under these 175 conditions. The results are discussed with respect to the strengths and weaknesses of 176 the model in estimating $\mathrm{C}$ and water balances in Europe before presenting conclusions 177 and avenues for future research.

178 
179

180

181

182

183

184

185

186

187

188

189

190

191

192

193

194

195

196

197

198

199

200

201

\section{Materials and Methods}

\subsection{Study sites and climate data}

Twelve grassland sites with long-term eddy flux measurements were included in the study to evaluate model performances. The study sites cover a broad gradient of geographic and climatic conditions (Table 1) as well as a variety of soil types and management practices (Table 2). The sites are located in Central and Western Europe (Fig. 1, left), distributed over a range of latitudes from United Kingdom (Easter Bush) to Portugal (Mitra), of longitudes from Ireland (Dripsey) to Hungary (Bugac-Puszta), and of elevations from sea level up to mountain sites located at about $1800 \mathrm{~m}$ a.s.l. (Table 1). Along these ranges, the mean annual temperature varies from 5.2 (Monte Bondone, Italy) to $14.3{ }^{\circ} \mathrm{C}$ (Mitra, Portugal) with mean annual precipitation rates from 520 (Bugac-Puszta, Hungary) to $1271 \mathrm{~mm}$ (Dripsey, Ireland). With respect to management, the dataset covers the gradient from semi-natural to intensively managed mixed grass species swards (in the presence of clover) and essentially includes vegetation types representative of the zone. Semi-natural grasslands are typified by extensive systems either grazed (with a stocking rate of $\sim 0.5-1.0 \mathrm{LSU}^{-1}$ $\mathrm{yr}^{-1}$ ) or not grazed (where forage production is limited to one cutting per year). Otherwise, the other sites are intensively managed by grazing and/or cutting and are supplied with relative large amounts of $\mathrm{N}$ fertilizer $\left(>200 \mathrm{~kg} \mathrm{~N} \mathrm{ha}^{-1}\right)$. It should be noted that the distinction between extensive and intensive grasslands may not be clear-cut. For instance, the unfertilized site of Amplero, grazed by a limited number of livestock units ( $\left.0.5 \mathrm{LSU} \mathrm{ha}^{-1} \mathrm{yr}^{-1}\right)$, qualifies as an intensive production system because 
it is grazed for a long period of time in the year (200 days), with intensive utilization of the sward and gain of $\mathrm{N}$ from returns by animals. At Easter Bush, the low impact of extensive system because the $\mathrm{N}$ fertilization treatment does not exceed the threshold

206 (>200 kg N ha ${ }^{-1}$ ) conventionally set for intensively managed grasslands (e.g. Bos et 207

\subsection{Flux measurements}

al., 2005).

Monthly and yearly summaries for the average temperature and total precipitation were obtained from the hourly weather data available for each site. The yearly reference evapotranspiration $\left(E T_{0}, \mathrm{~mm}\right)$ was also calculated, using the Penman-Monteith method, which uses an hourly time step (Allen, 2005). These weather summaries were the basis for calculating two bioclimatic indicators.

The aridity pattern (Fig. 1, right) is characterized by semi-arid to humid conditions, with the average value of De Martonne-Gottmann index (b) ranging from 10-20 at Mitra (Portugal) and Bugac-Puszta (Hungary) to 45 at Dripsey (Ireland). The climate of Mitra is typically warm and dry for a large part of the year, with hot summers. Bugac-Puszta represents a continental climate, with hot summers, rain showers and mildly cold winters. The site is characterized by annual water deficit, as well as the Mediterranean upland site of Amplero (Central Italy). The other sites are mostly humid, with values of the aridity index around 30-50.

Each study site was equipped with an eddy covariance system to determine the net 
224

225

226

227

228

229

230

231

232

233

234

235

236

237

238

239

240

241

242

243

244

245

ecosystem exchange (NEE) of $\mathrm{CO}_{2}$. For each site, details of the materials and software used are provided by published papers (Table 1). The eddy covariance system consisted of a fast response 3D sonic anemometer coupled with fast $\mathrm{CO}_{2}-\mathrm{H}_{2} \mathrm{O}$ analyzers measuring fluxes of $\mathrm{CO}_{2}$, latent and sensible heat, and momentum fluxes every 30 minutes. The flux data used in this study were downloaded from the European Fluxes Database Cluster (http://www.europe-fluxdata.eu). These data, previously filtered(quality checking and gap-filling) using methods based on friction velocity ( $\mathrm{u}^{*}$ filtering), contain inherent uncertainty (as detected by bootstrapping approach, after Reichstein et al., 2005 and Papale et al., 2006). We acknowledge that the random and systematic errors of eddy flux measurements could induce uncertainty and affect interpretation of data when eddy flux data were used for model calibration and validation (Lasslop et al., 2008). Random errors caused by poor measurement and sampling variability can be quite large at half-hourly time resolution, while systematic errors (biases) can be corrected (Aubinet et al., 2012). It is known that the correction can be insufficient to avoid propagation of uncertainties in the gap-filling procedure and in the partitioning of $\mathrm{C}$ exchanges into assimilation and respiration (Richardson et al., 2012). However, the absolute uncertainty in half-hourly measurements is reduced (down to $\sim 10 \%$ ) with daily or higher (monthly to annual) timescales and often equals the inter-annual variability of the measured fluxes (Hagen et al., 2006; Desai et al., 2008; Kroon et al., 2009).

\subsection{Model description}


The Pasture

Simulation

model

(PaSim,

version

5.3,

247 https://www1.clermont.inra.fr/urep/modeles/pasim.htm) simulates $\mathrm{C}$ and $\mathrm{N}$ cycling in

248 grassland ecosystems (mixed swards) at a sub-daily time step. The model has evolved

249

over time, starting as a simulator of dry matter production and associated flows of $\mathrm{C}$,

$250 \mathrm{~N}$ and water in productive pastures (Riedo et al., 1998). The biological $\mathrm{N}$ fixation by

251 clover is simulated by assuming that clover fraction in the sward is fixed for the

252 specific location (after Riedo et al., 1998). PaSim was later improved by Schmid et al.

253 (2001b) with respect to the production and diffusion of $\mathrm{N}_{2} \mathrm{O}$ (Riedo et al., 2002) the

254 exchange of $\mathrm{NH}_{3}$ with the atmosphere by Vuichard et al. (2007a, b), the animal

255 herbage selection and intake, and the effects of diet quality on the emissions of $\mathrm{CH}_{4}$

256 from grazing animals. More recently, Graux et al. (2011) further improved

257 functionalities to estimate the forage production and dry matter intake taking into

258 account selective grazing between vegetation compartments and the effect of high

259 temperatures on animals, while also simulating ruminant performance and enteric

$260 \mathrm{CH}_{4}$ emissions during grazing according to the energy content of the intake. The

261 livestock system considers change in body weight of the grazing livestock and

262 simulates the level of milk and meat production with heifers, dairy and suckler cows

263 during the grazing period.

264 The model consists of five interacting modules: microclimate, soil, vegetation,

265 herbivores and management. The soil biophysical module simulates soil temperature

266 and moisture profiles for different soil layers based on soil physical properties and

267 hourly weather inputs and simulated plant water use. The soil biogeochemical module, 
adapted by monthly time-step CENTURY's organic decomposition approach (Parton, 1988), evenly distributes litter into the whole soil profile. The litter is segregated into

270 its structural and substrate components, respectively supplying the structural and

271 metabolic soil pools. In addition, the soil organic matter is further separated into three

272 compartments (active, slow and passive) according to different decomposition rates.

273 Soil pools are interlinked to represent $\mathrm{C}$ and $\mathrm{N}$ first-order kinetics. The $\mathrm{N}$ cycle

274 considers $\mathrm{N}$ inputs to the soil via atmospheric deposition, fertilizer addition, symbiotic

275 fixation by legumes and animal faeces and urine. The inorganic soil $\mathrm{N}$ is available for

276 root uptake and is lost through the processes (leaching, volatilization and

277 nitrification/denitrification) leading to $\mathrm{N}_{2} \mathrm{O}$ and $\mathrm{N} 2$ emissions to the atmosphere. The

278 vegetation module estimates the assimilated $\mathrm{C}$ by photosynthesis and allocates it

279 dynamically to one root and three shoot compartments, each of which consisting of

280 four age classes. The transition from one age category to the next is done using

281 threshold time values to calculate the age of biomass in a compartment from the input

282 of younger material and the loss of older material. C losses from the system are

283 through animal milking, enteric $\mathrm{CH}_{4}$ emissions and from animal returns, and

284 ecosystem respiration. Accumulated aboveground biomass is either cut or grazed, or

285 enters a pool after senescing. Herbivores are considered during the time they were at

286 pasture (not during indoor periods). Management includes organic and mineral $\mathrm{N}$

287 fertilizations, mowing and grazing, setting by the user or optimized within the model

288 to achieve some objectives. 


\subsection{Parameterization and Simulation}

291

292

\subsubsection{Parameterization strategies}

293

In previous studies (Calanca et al., 2007; Vuichard et al., 2007b), PaSim was

294

evaluated for a temporary grassland at Oensingen (Switzerland) and an upland

295

permanent grassland at Laqueuille (France) based on a set of 26 parameters (Table 3).

296

We assumed that a common set of eco-physiological model parameters can be

297

established to simulate $\mathrm{C}_{3}$ grasslands (including grasses, forbs and legumes) under

298

contrasting climate and management regimes in Europe, while site-specific climate

299

and management conditions provide supplementary factors driving the actual

300

production of grasslands. Based on the set of parameters given in Table 3 and

301

sensitivity analysis results (Ben Touhami et al., 2013), the following two steps were

302

carried out to explore the parameter space and identify a common set of

303

eco-physiological model parameters for PaSim. First, the model was run at all sites

304

with two sets of default parameter values: temporary sown grassland (P_temp) and

305

upland permanent grassland (P_perm). Second, manual calibration was carried out for

306

these parameters, which were identified as influential parameters by Ben Touhami et

307

al. (2013). The values of some of these parameters were modified within their

308

plausible ranges (as from the published literature, documented by Graux, 2011) to

309

ensure realistic representation of a variety of outputs. The calibration work was

310

performed at all study sites together through a trial-and-error process comparing the

311

model predictions with observational data. The solutions obtained constitute a 
312 satisfactory performance for all output variables according to the metrics of Table 4.

313 Even though optimization methods are available (Trudinger et al., 2007; Wang et al.,

314 2009), the manual calibration is useful for modellers to get a reference parameter set

315 reflecting expert knowledge and simple adjustment strategies. It was proven that

316 optimization methods may be problematic in confronting the interaction between

317 parameters of complex models (Hollinger and Richardson, 2005; Richardson et al.,

318 2010). The model performance was evaluated for each site separately and with all

319 sites combined, by comparing the simulated $\mathrm{C}$ and water fluxes with data from eddy

320 flux towers.

321

322

\subsubsection{Model simulation and evaluation}

323 For each site, simulations were carried out with three sets of parameter values

324 described above for all available years in each site

325 PaSim was initialized via a spin-up process using the current weather input. In

326 particular, soil C pools were initialized to steady-state by running the model over 100

327 years by looping the available meteorology at each site following Lardy et al. (2011).

328 The results of the spin-up process matched the supplied soil $\mathrm{C}$ measurements with a

329 relative error of about $10 \%$ on average ( $\pm \sim 2 \%$ standard error).

330 The agreement of model outputs against the following five plant and soil variables

331 was examined, gross primary productivity (GPP, $\mathrm{kg} \mathrm{C} \mathrm{m}^{-2} \mathrm{~d}^{-1}$ ), ecosystem respiration

332 (RECO, $\mathrm{kg} \mathrm{C} \mathrm{m}^{-2} \mathrm{~d}^{-1}$ ), net ecosystem exchange (NEE, $\mathrm{kg} \mathrm{C} \mathrm{m}^{-2} \mathrm{~d}^{-1}$ ), soil water content

$333\left(\mathrm{~m}^{3} \mathrm{~m}^{-3}\right)$ and actual evapotranspiration $\left(\mathrm{ET}, \mathrm{mm} \mathrm{d}^{-1}\right)$. Ecosystem respiration (RECO) 
plays an important role in estimating global $\mathrm{C}$ balances of terrestrial ecosystems, and its knowledge is required to assess the GPP of such ecosystem (as a sum of NEE, and RECO, equations in appendixes A, B, C and D). Soil water content (SWC) and soil temperature (ST) were estimated for each of the six layers that make up the soil profile in PaSim (equations in appendixes $\mathrm{E}$ and $\mathrm{F}$ ).

Different performance indices and threshold criteria (Bennett et al., 2013) were used

340 to evaluate the model (Table 4). In particular, the goodness-of-fit $\mathrm{R}^{2}$ (coefficient of 341 determination) was calculated to assess the linear dependence between modelled and 342 observed data and the variance explained by the model. The modelling efficiency 343 (ME), the index of agreement (IA) and the root mean square error (RMSE) were 344 derived to assess quantitative differences. The mean bias (MB) is a measure of the 345 overall tendency of the model to under- or over-estimate (the systematic error) the 346 observations. The performance of the model was assessed on daily, weekly and 347 monthly time scales. 
349

350

351

352

353

354

355

356

357

358

359

360

361

362

363

364

365

366

367

368

369

370

\section{Results}

This section first describes the study sites. Then, the comparison between PaSim results obtained with three sets of parameter values (two previously established and one established in this study) and observed $\mathrm{C}$ and water fluxes is illustrated. The model improvement gained with the new parameterization is presented. As well, the impact of both site-specific characteristics and management options on model performances is illustrated, followed by a detailed analysis of the model performances with focus on $\mathrm{C}$ and water balances. Only exemplary results (selected output variables and sites) are reported graphically and the main outcomes discussed hereafter, while the full set of results is provided online supplementary material.

\subsection{The improvement of the model performance with the redefined parameter} values

The adjusted parameters (denoted P_new) essentially reflect that previously used at the permanent grassland site of Laqueuille (P_perm) (Table 3). This indicates that Laqueuille site resembles the European grasslands used in this study, with the exception of four parameters: light-saturated leaf photosynthetic rate for reproductive stage, light-saturated leaf photosynthetic rate for vegetative stage, maximum specific leaf area, and temperature dependence factor of the soil respiration. Even though a formal sensitivity analysis was not undertaken in this study, these parameters had a significant impact on model outputs in a previous study (Ben Touhami et al., 2013).

For three parameters, the new values lie between those in the previous studies. For the 
371 parameter governing soil respiration, previous modelling studies supported a default

372 value equal to 2 , which was substantially decreased (down to 0.7 ) to obtain simulated

373 respiration values closer to observations. Given its impact on the modelled RECO,

374 characterization of this parameter will require further studies.

375 The estimation of GPP and RECO was improved (Fig. 2) with the redefined common

376 set of eco-physiological parameters (Table 3). GPP was overestimated at all sites

377 using the $\mathrm{P} \_$temp parameter set with the exception of Oensingen (the site where that

378 parameter set was originally derived) and, to a lesser extent, of Amplero. Using

379 P_perm parameter set (permanent grassland), the bias of GPP was reduced at seven

380 out of 12 sites. Applying the redefined P_redif parameter set (Table 3), the bias of

381 GPP was further reduced for most of the sites except Oensingen, Bugac-Puszta and

382 Amplero (Fig. 2).

383 With both P_temp and P_perm parameter sets, RECO was overestimated for most of

384 the sites, with the exception of Oensingen and Amplero (Fig. 2). With P_perm, a

385 slight underestimation was also obtained at intensively-managed Laqueuille (Fig. 2).

386 When the redefined parameter set was used, the bias of RECO was reduced at all sites

387 but Oensingen and Amplero. Overall, the estimated ET has a good agreement with the

388 observed values with no real improvement with the redefined parameter values (Fig. 2

389 and Fig. A1).

390

391

3.2 The site variability of model performances with the redefined parameter

392

values 
393

394

395

396

397

398

399

400

401

402

403

404

405

406

407

408

409

410

411

412

413

414

Model performance in predicting GPP, RECO and ET (data aggregated on a weekly basis) is closely linked with site-specific conditions such as soil moisture (e.g. dry sandy soils versus humid soils). The model simulated well GPP and RECO for nine out of 12 sites. The exceptions were the sites of Amplero, Mitra and Bugac-Puszta (Fig. 3, Fig. 4 and Table 5), which are characterized by drier conditions than the other sites. The $\mathrm{R}^{2}$ for the estimated versus observed GPP was greater than 0.8 for most of the sites and was lower than 0.5 at Amplero only $\left(\mathrm{R}^{2}=0.40\right)$ (Fig. 3). Similar results were found when other indices, such as the slope of the regression, IA, ME and RMSE were taken into account (Table. 5). Compared with GPP estimations, similar model performances were found for RECO across sites, but $\mathrm{R}^{2}$ values for RECO were relatively lower than those obtained when simulating GPP. For RECO, $\mathrm{R}^{2}$ values were generally greater than 0.7 for most of the sites, but lower than 0.5 at Amplero $\left(\mathrm{R}^{2}=0.39\right)$ and Mitra $\left(\mathrm{R}^{2}=0.46\right)$ (Fig. 4). At Oensingen, the model underestimated RECO during winter time and there were also periods (e.g. 2007) when summer modelled RECO was below of that measured (Fig. 5). However, winter RECO underestimation was common to most of the sites (online supplementary material).

The model performance was satisfactory for predicting ET at most of the sites. Exceptions were dry sites such as Amplero, Bugac-Puszta and Mitra (Fig. A1).

\subsection{The impact of site characteristics and management practices}

Site characteristics and management practices were observed to have an important impact on the model ability to estimate RECO (Fig. 6), but they were less important 
415 when predicting GPP, NEE, ET, and soil temperature (data not shown). Concerning

416 management practices, the model tended to underestimate or overestimate RECO,

417 respectively for intensively and extensively managed grasslands (Fig. 6). The

418 occurrence of cutting or grazing had no significant impact on the model performance

419 in predicting RECO. The model tended to slightly underestimate RECO for

420 temporary-sown grasslands, while simulations of permanent grasslands were in good

421 agreement with measured data (Fig. 6). Concerning site-specific conditions, RECO

422 was underestimated for non-montane grasslands ( $<800 \mathrm{~m}$ a.s.1.) and overestimated for

423 mountain sites (Fig. 6).

424 An analysis of the normalized residuals (where each residual is the difference between the

425 predicted and observed values divided by the standard deviation) showed seasonal patterns, which

426 differed by site (Fig. 7). On average, the model slightly underestimated weekly-aggregated RECO

427 in winter in most sites, but significantly overestimated it in summer time on Laqueuille extensive,

428 Monte Bondone, Alinya, Bugac-Puszta, and Cabauw (Fig. 7). However, most of the residuals fall

429 within the upper limit of the $95 \%$ confidence interval.

430

$431 \quad 3.4 \mathrm{C}$ and water balances

432 The mean annual $\mathrm{C}$ fluxes (NEE, GPP and RECO) are meant as a synthesis and a

433 complement to the model performances of PaSim presented in this study. They

434 showed a good agreement with observations using the redefined parameter set (Fig. 8).

435 With these parameter values, the estimated NEE flux was on average $213 \mathrm{~g} \mathrm{C} \mathrm{m}^{-2} \mathrm{yr}^{-1}$,

436 which indicates a sink of $\mathrm{C}$ approaching the average NEE flux observed at the studied 


\begin{abstract}
437 sites (185 $\left.\mathrm{g} \mathrm{C} \mathrm{m}^{-2} \mathrm{yr}^{-1}\right)$ (Fig. 8). The estimated yearly average values of GPP (1220 $\mathrm{g}$ $\left.438 \mathrm{C} \mathrm{m}^{-2} \mathrm{yr}^{-1}\right)$ and $\mathrm{RECO}\left(1006 \mathrm{~g} \mathrm{C} \mathrm{m}^{-2} \mathrm{yr}^{-1}\right)$ are in agreement with the observed mean 439 values (1230 $\mathrm{g} \mathrm{C} \mathrm{m}^{-2} \mathrm{yr}^{-1}$ for GPP and $1046 \mathrm{~g} \mathrm{C} \mathrm{m}^{-2} \mathrm{yr}^{-1}$ for RECO) across all sites 440 (Fig. 8). As a consequence, the model overestimated the $\mathrm{C}$ sink by $15 \%$. This is 441 mainly due to RECO, which is underestimated while GPP is in good agreement with 442 observations. The average value of simulated ET (415 $\left.\mathrm{mm} \mathrm{yr}^{-1}\right)$ for all sites and years 443 was close to the average value of the observations (451 $\left.\mathrm{mm} \mathrm{yr}^{-1}\right)$, which corresponded 444 to an underestimation by $8 \%$ (Fig. 9).
\end{abstract}

445 
446

447

448

449

450

451

452

453

454

455

456

457

458

459

460

461

462

463

464

465

466

467

\section{Discussion}

\subsection{Model performance over European grasslands}

By evaluating PaSim at a variety of European sites, an improvement of model performances was obtained with using a common set of parameter values to estimate $\mathrm{C}$ and water fluxes at weekly and yearly time scales (Fig. 2, Fig. 8 and Table 3). The discrepancy between the observed and estimated GPP and RECO values was reduced compared with previous studies making us of parameter values obtained at specific conditions (Calanca et al., 2007; Ciais et al., 2010). For instance, Calanca et al. (2007) overestimated GPP of about $50 \%$ at Laqueuille (France).

\subsection{The spatial variability of the model performance}

The agreement between the observed and estimated GPP on arid sites (Bugac-Puszta, Amplero) is not as good as on other sites (Fig. 3). The mismatch between observed and estimated GPP values on these dry sites can be partially attributed to the fact that the model did not simulate soil water content fluctuations during summer time well (see effect of drought conditions for Bugac-Puszta, Fig. 2A and Amplero, Italy, Fig A3). Previous studies confirmed that extreme drought events may have a significant effect on C and water cycles (Ciais et al., 2005; Hussain et al., 2011). With all the slope coefficients less than 1 , the range of the simulated soil water content was smaller than the observed range, while the intercept was well above 0 (Fig. A4), indicating that the model overestimated the soil water content during dry periods and 
underestimated it the rest of time. As a consequence, the overestimated soil water content during drought periods could explain the slight overestimation of GPP (Fig. A2). In contrast, at Mitra (Portugal), the underestimated GPP can be partially attributed to the underestimated soil water content during the growing season (Fig. A5)

472 as water is the limitation factor of plant growth in arid regions. Underestimation of 473 GPP was also obtained at Amplero (Italy), but the incomplete information available 474 for this site (Fig. A3) about starting and ending dates of grazing (constant dates were 475 used) makes interpretation of results difficult.

476 Comparing with GPP, a similar model performance for RECO was found, but $\mathrm{R}^{2}$ for 477 RECO is relatively lower than GPP (Fig. 3). The lower $\mathrm{R}^{2}$ for RECO on most of the 478 sites is mainly due to the underestimated RECO during winter as, for instance, at 479 Bugac-Puszta (Fig.7, A2). On one hand the underestimated RECO during winter can 480 be attributed to underestimation of soil temperature in the same period as soil 481 respiration is sensitive to temperature. Soil respiration, one of the main components of 482 RECO, depends on soil moisture, clay content, soil organic matter and C assimilation (Bahn et al., 2008; Balogh et al., 2011; Migliavacca et al., 2011) and these are also the 484 drivers of PaSim. On another hand, the overestimated RECO at Bugac-Puszta is 485 partially due to overestimated GPP as more C substrate is available. A third reason 486 might be that the model overestimated soil moisture content (Fig. A2 and Fig. A5) 487 since soil moisture is one of the most important limiting factors of soil respiration 488 especially in arid and semi-arid regions (Balogh et al., 2011). At Amplero and Mitra, 489 RECO underestimation follows GPP underestimation (Fig. A3 and Fig. A5). Indeed, 
490

491

492

493

494

495

496

497

498

499

500

501

502

503

504

505

506

507

508

509

510

511

RECO is intimately related to C supply (Bahn et al., 2008; Migliavacca et al., 2011).

\subsection{Effect of site-specific conditions and management practices}

Management practices affect grassland production and greenhouse gas emissions from grassland systems (Schmitt et al., 2010; Zeeman et al., 2010; Luo et al., 2012; Peichl et al., 2012). In this study, PaSim underestimated RECO for intensively-managed grasslands such as Oensingen and Amplero and overestimated it for extensively-managed grasslands (Fig. 6, 7). It is known that intensive management practices can introduce pronounced changes to soil physical structure, which in turn impact the soil water transport processes and the soil heterotrophic respiration (Moyano et al., 2012; Ball, 2013). It is the case for the present study as PaSim did not simulate adequately soil water fluctuations (Fig. 5, Fig. A2 and Fig. A3). At Oensingen (Switzerland), the model did not represent well the soil temperature (Fig. 5. This can be mainly attributed to the disturbance of management, which changed the soil structure when converting cropland into grassland at Oensingen in 2001, considering that tillage changes soil physical structure and, in turn, water and energy transport processes (Acharya et al., 2012). The human management could also modify microbial component and diversity (Cantarel et al., 2012), which significantly impacts on the soil respiration (Allison et al., 2010; Wieder et al., 2013). Moreover, the possibility to introduce more uncertainties is high due to imprecise input management information such as grazing, cutting, and fertilization rate and timing. 
512

513

51

515

516

517

518

519

520

521

522

523

524

525

526

527

528

529

\subsection{Limitations and further improvement}

Referring to the model performance discussed above, certain modules of PaSim were identified as worthy of further development. One is the soil energy balance module because the model underestimated soil temperature when air temperature was high in summer (Fig. A5) and overestimated soil temperature in winter when air temperature is low (Fig. 5, Fig. A2, Fig. A3 and Fig. A5). The soil water transport module is also critical because soil water fluctuations were not well captured by the model (Fig. 5, Fig. A2, Fig. A3 and Fig. A5), especially on arid and semi-arid grasslands. Moreover, the effect of standing biomass on the energy balance (with shading and albedo) has not been investigated.

The choice of eco-physiological parameters used and calibrated manually in this study also requires a forma quantification of the parameter uncertainties introduced in regional studies. The interaction between model parameters is also an issue. For example, specific leaf area $(s l a)$, which depends on the maximum value set for it (slam), interacts in PaSim with C allocation-parameters across different organs of the plant. A higher sla could induce a lower allocation of assimilated C to leaf, which may be not the case in reality. 


\section{Conclusions and perspectives}

531

532

\subsection{Summary of findings of the regional-scale analysis}

A regional-scale analysis of $\mathrm{C}$ and water cycles was performed on a variety of

European grassland sites using a process-based model (PaSim) with a single set of

eco-physiological parameters. It was shown that: 1) variables of $\mathrm{C}$ and water cycles

(mainly GPP, RECO and ET) can be reasonably simulated by PaSim at European

scale using a common set of parameter values; 2) better model performances are

obtained at more humid sites; 3) RECO tends to be underestimated in

intensively-managed grasslands and overestimated at sites when extensive

management practices are adopted.

541 The parameterization for mechanistic simulation of grasslands (with biogeochemical

542 capabilities) is a general way to facing regional studies. We have pursued in this study

543 the question of to what extent calibration can improve the parameterization of a

544 complex grassland model for regional-scale simulations in Europe. Acting upon the

545 most influential parameters of PaSim, we have derived a set of parameter values of

546 general validity in Europe. Even if for specific purposes process-based models need to

547 be parameterized on a site-specific basis, our multi-dataset procedure demonstrates

548 that it is possible to find global estimates for those parameters that encompass a wide

549 range of conditions. The accurate estimation of $\mathrm{C}$ and water fluxes relies on the

550 mechanistic representation of key ecosystem processes, with parameters that can be

551 related to physical quantities, thus the perspective of using a regionally calibrated

552 model regulating energy and matter exchanges is more interesting than applying 
553

554

555

556

557

558

559

560

561

562

563

564

565

566

567

568

569

570

571

572

573

574

statistical models (Laniak et al., 2013). In addition, statistical model estimations may involve significant levels of collinearity among predictor variables such as temperature and precipitation. They also rely on the assumption of stationarity (e.g. assuming that past relationships will hold in the future, even if factors such as climate and management evolve) and are subject to problems of low signal-to-noise ratios in yield or weather records in many locations (Lobell and Burke, 2010). The main finding is that the satisfactory performance obtained over contrasting climate conditions and management options justify the use of PaSim in regional studies on $\mathrm{C}$ and water fluxes in Europe. In C-water flux studies, this is especially relevant when daily-resolution outputs are mainly analysed in temporally-aggregated form - that is, the interest is in weekly, monthly or higher timeframes (e.g. Wallach and Thorburn, 2014).

\subsection{Future work on grassland modelling}

Our results indicate further model development is needed to address specific needs and this is critical under the pressure of a changing climate and related extreme weather events, potentially altering the $\mathrm{C}$ cycles at different scales (Field et al., 2011). A first issue is that heat waves and dry spells have (favouring conditions of aridity) a direct effect on $\mathrm{CO}_{2}$ fluxes because warmer temperatures and soil moisture shortage affect both photosynthesis and respiration. Moreover, as changes in seasonal water availability have pronounced effects on individual species, a prominent role is suggested for species interactions in ecosystem responses to climate changes (Suttle et 
575 al., 2007). Adaptation and functional biodiversity would dampen down the effect of

576 climate extremes on the $\mathrm{C}$ cycle, but the bases for biological adaptation and the role of

577 biodiversity are still unclear (Reichstein et al., 2013b). The use of functional traits of

578 plants, for which plant species are classified into functional types based on vegetative

579 and reproductive traits, proposed by Cruz et al. (2002) can be a promising avenue for

580 future research (Duru et al., 2013). But the level of detail of this study is too low to

581 draw conclusions about the relationship between model parameters and phenotypic

582 traits.

583 To obtain reliable estimates of the sign (source or sink) and magnitude of C-cycle

584 feedbacks, future research should provide a mechanistic basis for inferring effects of

585 extreme meteorological events on the $\mathrm{C}$ cycle. This would also help capturing the

586 impacts of drought events on grasslands because drought avoidance of grassland

587 plants mainly depends on rooting depth and soil water reserves. Concepts by Baker et

588 al. (2008) and Sheikh et al. (2009), which consider root access to the stored water in

589 the deep soil water during the drought season, could be integrated into PaSim.

590 The soil temperature module is another area of the model to be improved to better

591 predict soil temperature over winter. This is especially critical for high-altitude

592 grasslands, where vegetative growth restarts at snowmelt. This would also improve

593 the estimation of soil respiration, for which soil temperature is a key driver.

594 Moreover, we acknowledge that the dynamics of aboveground biomass accumulation

595 (either cut for yield production or grazed by animals) were not considered in the study

596 design. Biomass data are mostly discontinuously measured and rather large 
597 uncertainties on biomass measurements (mainly owing to spatial heterogeneity) may 598 hinder model evaluation (Vuichard, 2007b). A better model performance (yet 599 integrating biomass measurements) could be attained by optimizing model parameters 600 through model-data fusion methods such as Bayesian calibration (van Oijen et al., 601 2011). Studies of this type are underway on PaSim (Ben Touhami et al., 2012a, b) 602 with attention given to the interaction among parameters.

603 The improvements of PaSim also include the development of scalable solutions with 604 fundamental plant science research (a broad range of basic impact processes, open to 605 a wide range of plant types) and transition of software engineering technology into 606 modelling practice (Martin et al., 2011; Lardy et al., 2014), while addressing 607 re-usability issues and inter-linking of model components (Donatelli et al., 2012).

608 For managed grasslands, complete management information is often unavailable for 609 regional studies. High-quality grassland management data are needed to better 610 understand their effects on the soil physical structure and C storage (Flechard et al., 611 2007; Schmitt et al., 2010; Chang et al., 2013).

612 The model improvement actions are ongoing under the guidance and conditions laid 613 down by a number of international projects and initiatives (e.g. AgMIP, 614 http://www.agmip.org), and will be expanded by the EU-FP7 project 615 MODEXTREME (http://modextreme.org). 


\section{Acknowledgments}

618 The results of this research were obtained within an international research project 619 named "FACCE MACSUR - Modelling European Agriculture with Climate Change 620 for Food Security, a FACCE JPI knowledge hub". The data used were obtained with 621 the support of EU projects CarboEurope-IP (FP6 GOCE-CT-2003-505572) and 622 CARBO-Extreme (FP7-ENV-2008-1-226701). We thank Partner Institutions for 623 providing grassland data. We also acknowledge technical support from the European 624 Fluxes Database Cluster (http://www.europe-fluxdata.eu). Several reviewers and the 625 editors helped considerably in improving the manuscript. 


\section{APPENDICES}

\section{Appendix B - Total plant respiration}

A single process of respiration is associated with growth (Thornley, 1998). A component of this respiratory flux is deemed to be maintenance respiration (generally associated with the re-synthesis of degrading tissue), while also taking into account the energy required for mineral uptake. The dependence of respiratory components on C substrate supply is represented by separating C substrate from structure and coupling the respiration flux to photosynthesis. This allows simulating variation in the fractions of total plant respiration associated with different processes during plant development.

Total plant respiration, $R_{p l, t o t}\left(\mathrm{~kg} \mathrm{C} \mathrm{m}^{-2} \mathrm{~d}^{-1}\right)$, is given by: 
$R_{G}$ and $R_{m}$ stand for growth and maintenance respiration, respectively, referred to shoot (index $s h$ ) and root (index $r t$ ). $R_{N}$ is the respiratory flux associated with uptake of $\mathrm{N}$ from the soil solution. The terms $R_{m, r t}, R_{G, r t}$ and $R_{N}$ are soil respiratory fluxes 662

666

667

668

669

670

671

672

673

674

\section{Growth respiration rates}

The two respiration fluxes needed to produce energy for the growth of shoots and roots, $R_{G, s h}$ and $R_{G, r t}\left(\mathrm{~kg} \mathrm{C} \mathrm{m}^{-2} \mathrm{~d}^{-1}\right)$, respectively, are calculated as:

$R_{G, S h}=I_{C, G_{S h}} \cdot\left(\frac{1}{Y_{G, p l}}-1\right)$

$R_{G, r t}=I_{C, G_{r t}} \cdot\left(\frac{1}{Y_{G, p l}}-1\right)$

The term $1 / Y_{G, p l}$ is an efficiency measure representing the $\mathrm{kg}$ of $\mathrm{C}$ required to create 1 $\mathrm{kg}$ of structural C, $Y_{G, p l}$ being the photosynthetically-assimilated $\mathrm{C}$ initially allocated to substrate $\mathrm{C}$ reserves and then used for growth and maintenance of tissues. For the fraction required for growth, growth rates $\left(\mathrm{kg} \mathrm{C} \mathrm{m} \mathrm{m}^{-1}\right)$ are calculated for aboveground $\left(I_{C, G_{s h}}\right)$ and belowground $\left(I_{C, G_{r t}}\right)$ biomass, based on allocation values occurring during the vegetative stage $\left(I_{C, G_{s h, v e g}}\right.$ and $\left.I_{C, G_{r t, v e g}}, \mathrm{~kg} \mathrm{C} \mathrm{m}^{-2} \mathrm{~d}^{-1}\right)$, modified in favour of aboveground biomass during the reproductive stage. The coefficient $Y_{G, p l}$ is set equal to 0.75 to represent plant growth efficiency $\left(\operatorname{kg~C}(\operatorname{kg~C})^{-1}\right)$.

$\mathrm{C}$ allocation fluxes into roots $\left(I_{C, G_{r t}}\right)$ and aboveground $\left(I_{C, G_{s h}}\right)$ plant parts are as follows:

$I_{C, G_{r t}}=I_{C, G_{r t, v e g}}-f_{\text {devstage }} \cdot I_{C, G_{r t} \text {,veg }}$

$I_{C, G_{\text {sh }}}=I_{C, G_{\text {sh veg }}}+f_{\text {devstage }} \cdot I_{C, G_{r t \text { veg }}}$

Where $f_{\text {devstage }}$ is a factor depending on the plant development stage.

The terms $I_{C, G_{s h, v e g}}$ and $I_{C, G_{r t, v e g}}$ are calculated on a constant growth rate at $20{ }^{\circ} \mathrm{C}\left(I_{C, G 20}\right.$, usually set equal to $\left.150 \mathrm{~kg}^{2}(\mathrm{~kg} \mathrm{C})^{-1}(\mathrm{~kg} \mathrm{~N})^{-1}\right)$, applied to the cumulative structural biomass of roots and shoots $\left(W_{s h}, W_{r t}, \mathrm{~kg} \mathrm{DM} \mathrm{m}^{-2}\right)$ and modulated by factors of 
temperature $\left(f_{T, G}\right)$ and substrate $\mathrm{C}$ and $\mathrm{N}$ concentrations in shoots and roots $\left(C_{s h}, C_{r t}\right.$,

685 $\left.\operatorname{kg~C}(\mathrm{kg} \mathrm{DM})^{-1} ; N_{s h}, N_{r t}, \mathrm{~kg} \mathrm{~N}(\mathrm{~kg} \mathrm{DM})^{-1}\right)$, as follows:

$I_{C, G_{\text {sh veg }}}=I_{C, G 20} \cdot f_{T, G} \cdot C_{s h} \cdot N_{s h} \cdot W_{s h}$

$$
I_{C, G_{r t, v e g}}=I_{C, G 20} \cdot f_{T, G} \cdot C_{r t} \cdot N_{r t} \cdot W_{r t}
$$

\section{Maintenance respiration rates}

The respiration fluxes to maintain metabolic processes (those that do not result in a net increase in plant dry matter) of roots $\left(R_{m, r t}\right)$ and shoots $\left(R_{m, s h}\right)$ are a function of substrate $\mathrm{C}$ concentration $\left(C, \mathrm{~kg} \mathrm{C} \mathrm{kg} \mathrm{DM}{ }^{-1}\right)$, structural biomass $\left(W_{s h} \cdot f_{C, s h}, W_{r t} \cdot f_{C, r t}\right)$ and a temperature-dependent stress factor (Table 3):

$R_{m, s h}=\frac{C}{C+K_{C, m a i}} \cdot R_{m, s h, t e m p}$

$R_{m, r t}=\frac{C}{C+K_{C, m a i}} \cdot R_{m, r t, t e m p}$

where $K_{C, \text { mai }}$ is a maintenance respiration parameter, set equal to $0.03 \mathrm{~kg}$ substrate $\mathrm{C}$ (kg structural DM) $)^{-1} \mathrm{~d}^{-1}$. The terms $R_{m, \text { sh,temp }}$ and $R_{m, r t \text { temp }}$ are temporary shoot and root maintenance respiration, respectively, as follows:

$R_{m, \text { sh,temp }}=f_{T, s h} \cdot \sum_{j=1}^{4} k_{m a i, j, 20} \cdot W_{s h, j} \cdot f_{C, s h}$

$R_{m, r t, t e m p}=f_{T, r t} \cdot \sum_{j=1}^{4} k_{m a i, j, 20} \cdot W_{r t, j} \cdot f_{C, r t}$

These maintenance respiration factors are transient in nature since they apply to temporary values. Both shoot and root biomasses are indeed divided into four state variables representing four age categories $(j=1, \ldots, 4)$, for which the following values are given for the maintenance respiration parameter at $20{ }^{\circ} \mathrm{C}, k_{m a i, j, 20}(\mathrm{~kg} \mathrm{C}$ $\mathrm{kg}^{-1}$ structural C d $\left.\mathrm{d}^{-1}\right): 0.020(j=1), 0.020(j=2), 0.015(j=3), 0.010(j=4)$.

The terms $f_{C, s h}$ and $f_{C, r t}\left(\mathrm{~kg} \mathrm{C} \mathrm{kg}^{-1} \mathrm{DM}\right)$ are fractional $\mathrm{C}$ content in shoot and root structural dry matter, respectively (reference values are 0.50 and 0.39 , respectively).

\section{$N$ uptake respiration rate}

The respiration flux associated with $\mathrm{N}$ uptake $\left(R_{N}, \mathrm{~kg} \mathrm{C} \mathrm{m}^{-2} \mathrm{~d}^{-1}\right)$ is:

$R_{N}=k_{N} \cdot I N_{\text {soil }, r t}$

where $I N_{\text {soil, rt }}\left(\mathrm{kg} \mathrm{Nm}^{-2}\right)$ is the mineral $\mathrm{N}\left(\mathrm{NO}_{3}^{-}-\mathrm{N}^{-}\right.$and $\left.\mathrm{NH}_{4}{ }^{+}-\mathrm{N}\right)$ uptake by the sward, 
713 and $k_{N}$ is the respiratory cost of $\mathrm{N}$ uptake (the reference value being $0.45 \mathrm{~kg} \mathrm{C} \mathrm{kg}^{-1} \mathrm{~N}$ ).

\section{Appendix C - Heterotrophic soil respiration}

Apart the biological activity of roots and associated micro-organisms, the flux of $\mathrm{CO}_{2}$ from the soil to the atmosphere is the result of the production of $\mathrm{CO}_{2}$ from the activity of heterotrophic bacteria and fungi living on litter and in the root-free soil (after Parton, 1988). The soil organic carbon (SOC) pool is divided into five pools with different turnover times ranging from 0.5 to 1500 years. An additional component is given by the amount of $\mathrm{C}$ released as exudates (exu) from roots into the soil, estimated as a fraction of plant substrate $\mathrm{C}$. The litter in decomposition over the total soil depth splits into its structural and substrate components, supplying the structural (str) and metabolic (met) soil pools respectively. Other three compartments with different decomposition rates include active (act), slow (slo) and passive (pas) pools of SOC, consisting of the microbial biomass, refractory components of litter and highly humified organic compounds respectively.

Total heterotrophic soil respiration, $R_{S O C}\left(\mathrm{~kg} \mathrm{C} \mathrm{m}^{-2} \mathrm{~d}^{-1}\right)$, is given by:

$R_{\text {SoC }}=R_{\text {str }}+R_{\text {met }}+R_{\text {exu }}+R_{\text {act }}+R_{\text {slo }}+R_{\text {pas }}$

\section{Soil respiration from structural organic matter}

The respiration flux associated with structural $\operatorname{SOC}\left(R_{s t r}, \mathrm{~kg} \mathrm{C} \mathrm{m}^{-2} \mathrm{~d}^{-1}\right)$ is:

$R_{s t r}=\left(1-f_{\text {lig,str }}\right) \cdot f_{r, s t r} \cdot f_{C, s t r}+f_{\text {lig,str }} \cdot f_{r, s t r, l i g} \cdot f_{C, s t r}$

The microbial respiration parameter for the decomposition of the structural pool, $f_{r, s t r}$, and of lignin, $f_{r, s t r l i g}$, are set equal to 0.55 and 0.3 , respectively. The term $f_{\text {lig,str }}$ is the fraction of lignin in structural soil organic matter. The fraction of $\mathrm{C}$ in the structural plant residue, $f_{C, s t r}$, is as follows:

$f_{C, s t r}=k_{s t r} \cdot W_{C, s t r}$

where $k_{s t r}\left(\mathrm{~kg} \mathrm{C} \mathrm{m}^{-2} \mathrm{~d}^{-1}\right)$ is the decomposition rate for the structural pool and $W_{C, s t r}(\mathrm{~kg}$ $\mathrm{C} \mathrm{m}^{-2}$ ) is the $\mathrm{C}$ content in structural fraction of plant residue (depending on temperature, lignin, texture and water content). 
743

744

745

746

747

748

749

750

751

752

753

754

755

756

757

758

759

760

761

762

763

764

765

766

767

768

769

770

771

772

Soil respiration from metabolic organic matter

The respiration flux associated with metabolic $\operatorname{SOC}\left(R_{m e t}, \mathrm{~kg} \mathrm{C} \mathrm{m}^{-2} \mathrm{~d}^{-1}\right)$ is:

$R_{m e t}=f_{r, m e t} \cdot f_{C, m e t}$

The microbial respiration parameter for the decomposition of the metabolic pool, $f_{r, m e t}$, is set equal to 0.55 . The fraction of $\mathrm{C}$ in metabolic pool, $f_{C, \text { met }}\left(\mathrm{kg} \mathrm{C} \mathrm{m}^{-2}\right)$, is calculated assuming linear kinetics.

Soil respiration from exudates

The respiration flux associated with root exudates $\left(R_{\text {exu }}, \mathrm{kg} \mathrm{C} \mathrm{m}^{-2} \mathrm{~d}^{-1}\right)$ is:

$R_{\text {exu }}=f_{r, \text { exu }} \cdot f_{C, \text { exu }}$

The parameter $f_{r \text {,exu }}$ is set equal to 0.75 . The term $f_{C \text {,exu }}\left(\mathrm{kg} \mathrm{C} \mathrm{m}^{-2}\right)$ is $\mathrm{C}$ substrate output for root exudation.

\section{Soil respiration from active organic matter}

The respiration flux associated with active $\operatorname{SOC}\left(R_{a c t}, \mathrm{~kg} \mathrm{C} \mathrm{m}^{-2} \mathrm{~d}^{-1}\right)$ is:

$R_{\text {act }}=f_{r, a c t} \cdot f_{C, a c t}$

The fraction of $\mathrm{C}$ in active pool, $f_{C, a c t}\left(\mathrm{~kg} \mathrm{C} \mathrm{m}^{-2}\right)$, is calculated as follows:

$f_{r, a c t}=0.85-0.68 \cdot\left(f_{\text {clay,ah }}+f_{\text {silt }, a h}\right)$

where $f_{\text {clay }}$ and $f_{\text {silt }}$ are fractions of clay and silt, respectively.

Soil respiration from slow organic matter

The respiration flux associated with slow $\operatorname{SOC}\left(R_{\text {slo }}, \mathrm{kg} \mathrm{C} \mathrm{m}^{-2} \mathrm{~d}^{-1}\right)$ is:

$R_{\text {slo }}=f_{r, s l o} \cdot f_{C, s l o}$

The microbial respiration parameter for the decomposition of the slow pool, $f_{r, s l o}$, is set equal to 0.55 . The fraction of $\mathrm{C}$ in slow fraction, $f_{c, \text { met }}(\mathrm{kg} \mathrm{C} \mathrm{m})$, is calculated as follows.

$f_{r, s l o}=k_{s l o} \cdot W_{C, s l o}$

$k_{s l o}=k_{s l o, 20} \cdot k_{d e c, t} \cdot k_{d e c, \theta}$ $W_{C, s l o}\left(\mathrm{~kg} \mathrm{C} \mathrm{m}^{-2}\right)$ is the $\mathrm{C}$ content in slow pool (depending on temperature, lignin, texture and water content). The term $k_{s l o, 20}\left(\mathrm{~d}^{-1}\right)$ is the turnover rate for slow $\mathrm{C}$ pool at 
$77320{ }^{\circ} \mathrm{C}$, equal to 0.00027 . The terms $k_{d e c, t}$ and $k_{d e c, \theta}$, are factor activities of soil organic 774 matter for temperature and water content, respectively.

775

776 Soil respiration from passive organic matter

777 The respiration flux associated with active $\mathrm{SOC}\left(R_{\text {pas }}, \mathrm{kg} \mathrm{C} \mathrm{m}^{-2} \mathrm{~d}^{-1}\right)$ is:

$778 \quad R_{\text {pas }}=f_{r, p a s} \cdot f_{C, p a s}$

779 The microbial respiration parameter for the decomposition of the passive pool, $f_{r \text {,pas }}$, is 780 set equal to 0.55 . The fraction of $\mathrm{C}$ in passive pool, $f_{C p, a s}\left(\mathrm{~kg} \mathrm{C} \mathrm{m}^{-2}\right)$, is calculated 781 assuming linear kinetics.

782

783

784

785

786

\section{Appendix D - Respiration from grazing animals}

787 The amount of ingested $\mathrm{C}$ is estimated as follows:

$I_{C, v e g \rightarrow a n i}=\left(f_{C, s h}+C\right) \cdot \frac{W_{s h}}{W_{s h, t o t}} \cdot I_{\text {veg } \rightarrow \text { ani }}$

789 where $\left(I_{v e g \rightarrow \text { ani }}, \mathrm{kg} \mathrm{DM} \mathrm{m} \mathrm{m}^{-2} \mathrm{~d}^{-1}\right)$ is the amount of ingested dry matter, which increases 790 with the aboveground plant biomass $\left(W_{s h, t o t}, \mathrm{~kg} \mathrm{DM} \mathrm{m}^{-2}\right)$ available for the animals 791 ( $W_{s h}, \mathrm{~kg} \mathrm{DM} \mathrm{m}^{-2}$, is the cumulative structural aboveground biomass), limited by the 792 maximum ingestion capacity the animal is able to maintain $\left(I_{\max }\right.$, whose reference 793 value is $16 \mathrm{~kg} \mathrm{DM} \mathrm{d}^{-1}$ animal $^{-1}$ ).

794 
The calculation of temperature in each soil layer is based on the energy balance

797 equations for the different soil layers (Campbell, 1985; Monteith, 1965; Shuttleworth 798 and Wallace, 1985):

$T_{s}^{*}(h)=0.6 \cdot T_{s}(h)+(1-0.6) \cdot T_{s}^{\prime}(h)$

800 Where $T_{s}(h)(\mathrm{K})$ is the soil temperature at the midpoint of the $\mathrm{i}^{\text {th }}$ layer in the present

801 time step, $T_{s}(h)(\mathrm{K})$ is soil temperature in the same layer but one time step in the past,

802 and $T^{*}(h)(\mathrm{K})$ is temperature in the $\mathrm{i}^{\text {th }}$ layer at some time between the two time steps.

803

804 Appendix F - Soil water balance

805 The water content in the different soil layers determines photosynthesis and stomatal

806 conductance, soil evaporation, and rates of soil biological processes, and is used to

807 calculate soil temperature in the different layers, which influences belowground plant

808 processes, soil heat flux, and soil biological processes. Values of the soil matrix

809 potential in soil layer $h, \psi(h)(\mathrm{m})$, is related to the water content in the same layer,

$810 \theta_{s}(h)\left(\mathrm{m}^{3} \mathrm{~m}^{-3}\right)$ by the soil moisture characteristic (Campbell, 1985):

$811 \quad \theta_{s}(h)=\theta_{s, s a t}(h) \cdot\left[\frac{\psi_{e}(h)}{\psi(h)}\right]^{\frac{1}{b(h)}}$

812 where $\theta_{s, s a t}(h)\left(\mathrm{m}^{3} \mathrm{~m}^{-3}\right)$ is the saturation soil water content in soil layer $h, \psi_{e}(h)$ is the 813 air entry water potential (m) in soil layer $h, b(h)$ is a physical parameter for soil layer $814 h$. 


\section{References}

Acharya, B.S., Rasmussen, J., Eriksen, J., 2012. Grassland carbon sequestration and emissions following cultivation in a mixed crop rotation. Agriculture, Ecosystems \& Environment 153, 33-39. doi:10.1016/j.agee.2012.03.001

Addiscott, T.M., Whitmore, A.P., 1987. Computer simulation of changes in soil mineral nitrogen and crop nitrogen during autumn, winter and spring. The Journal of Agricultural Science 109, 141-157. doi:10.1017/S0021859600081089

Aires, L.M.I., Pio, C.A., Pereira, J.S., 2008. Carbon dioxide exchange above a Mediterranean C3/C4 grassland during two climatologically contrasting years. Global Change Biology 14, 539-555. doi:10.1111/j.1365-2486.2007.01507.x

Allen, R.G., Walter, I.A., Elliot, R.L., Howell, T.A., Itenfisu, D., Jensen, M.E., Snyder, R., 2005. The ASCE standardized reference evapotranspiration equation. American Society of Civil Engineers, Reston.

Allison, S.D., Wallenstein, M.D., Bradford, M.A., 2010. Soil-carbon response to warming dependent on microbial physiology. Nature Geoscience 3, 336-340. doi:10.1038/ngeo846

Ammann, C., Flechard, C.R., Leifeld, J., Neftel, A., Fuhrer, J., 2007. The carbon budget of newly established temperate grassland depends on management intensity. Agriculture, Ecosystems \& Environment 121, 5-20. doi:10.1016/j.agee.2006.12.002

Ascough, J.C., McMaster, G.S., Andales, A.A., Hansen, N.C., Sherrod, L.A., 2007. Evaluating GPFARM crop growth, soil water and soil nitrogen components for Colorado dryland locations. Transactions of the ASABE 50, 1565-1578.

Aubinet, M., Vesala, T., Papale, D., 2012. Eddy covariance: A practical guide to measurement and data analysis. Springer, Dordrecht.

Bahn, M., Rodeghiero, M., Anderson-Dunn, M., Dore, S., Gimeno, C., Droesler, M., Williams, M., Ammann, C., Berninger, F., Flechard, C., Jones, S., Balzarolo, M., Kumar, S., Newesely, C., Priwitzer, T., Raschi, A., Siegwolf, R., Susiluoto, S., Tenhunen, J., Wohlfahrt, G., Cernusca, A., 2008. Soil respiration in European grasslands in relation to climate and assimilate supply. Ecosystems 11, 1352-1367. doi:10.1007/s10021-008-9198-0

Baker, I.T., Prihodko, L., Denning, A.S., Goulden, M., Miller, S., da Rocha, H.R., 2008. Seasonal drought stress in the Amazon: Reconciling models and observations. Journal of Geophysical Research 113, G00B01. doi:10.1029/2007JG000644

Ball, B.C., 2013. Soil structure and greenhouse gas emissions: a synthesis of 20 years of experimentation. European Journal of Soil Science 64, 357-373. doi:10.1111/ejss.12013

Balogh, J., Pintér, K., Fóti, S., Cserhalmi, D., Papp, M., Nagy, Z., 2011. Dependence of soil respiration on soil moisture, clay content, soil organic matter, and $\mathrm{CO}_{2}$ uptake in dry grasslands. Soil Biology and Biochemistry 43, 1006-1013. doi:10.1016/j.soilbio.2011.01.017

Ben Touhami, H., Lardy, R., Barra, V., 2012a. Bayesian calibration of the Pasture Simulation Model (PaSim) to simulate European grasslands under climate extremes: case study at Stubai (Austria). $11^{\text {th }}$ PSAM \& ESREL Conference, 25-29 June, Helsinki, Finland, 1, 567-577.

Ben Touhami, H., Lardy, R., Gilgen, A., Buchmann, N., Bellocchi, G., 2012b. Bayesian calibration of the Pasture Simulation Model (PaSim) to simulate Swiss grasslands under climate extremes. $12^{\text {th }}$ Congress of the European Society for Agronomy, 20-24 August, Helsinki, 
Finland, 441-5.

860

861

862

863

864

865

866

867

868

869

870

871

872

873

874

875

876

877

878

879

880

881

882

883

884

885

886

887

888

889

890

891

892

893

894

895

896

897

898

899

900

901

902
Ben Touhami, H.B., Lardy, R., Barra, V., Bellocchi, G., 2013. Screening parameters in the Pasture Simulation model using the Morris method. Ecological Modelling 266, 42-57. doi:10.1016/j.ecolmodel.2013.07.005

Bennett, N.D., Croke, B.F.W., Guariso, G., Guillaume, J.H.A., Hamilton, S.H., Jakeman, A.J., Marsili-Libelli, S., Newham, L.T.H., Norton, J.P., Perrin, C., Pierce, S.A., Robson, B., Seppelt, R., Voinov, A.A., Fath, B.D., Andreassian, V., 2013. Characterising performance of environmental models. Environmental Modelling \& Software 40, 1-20. doi:10.1016/j.envsoft.2012.09.011

Bondeau, A., Kicklighter, D.W., Kaduk, J., The Participants of the Potsdam NdP Model intercomparison, 1999. Comparing global models of terrestrial net primary productivity (NPP): importance of vegetation structure on seasonal NPP estimates. Global Change Biology 5, 35-45. doi:10.1046/j.1365-2486.1999.00005.x

Bondeau, A., Smith, P.C., Zaehle, S., Schaphoff, S., Lucht, W., Cramer, W., Gerten, D., 2007. Modelling the role of agriculture for the $20^{\text {th }}$ century global terrestrial carbon balance. Global Change Biology 13, 679-706. doi:10.1111/j.1365-2486.2006.01305.x

Bos, J.F.F., Pflimlin, A., Aarts, H.F.M., Vertès, F., 2005. Nutrient management at farm scale. How to attain policy objectives in regions with intensive dairy farming? Plant Research International Report 83, Plant Research International, Wageningen, 260 pp.

Bright, K.P., Sherlock, R.A., Lile, J., Wastney, M.E., 2000. Development and use of a whole farm model for dairying. In: Halloy, S., Williams, T. (Eds.), Applied complexity - from neural nets to managed landscapes. NZ Institute for Crop and Food Research, Christchurch, pp. 382-389.

Brisson, N., Gary, C., Justes, E., Roche, R., Mary, B., Ripoche, D., Zimmer, D., Sierra, J., Bertuzzi, P., Burger, P., 2003. An overview of the crop model STICS. European Journal of Agronomy 18, 309-332. doi:10.1016/S1161-0301(02)00110-7

Butler, M.P., Davis, K.J., Denning, A.S., Kawa, S.R., 2010. Using continental observations in global atmospheric inversions of CO2: North American carbon sources and sinks. Tellus B 62, 550-572. doi:10.1111/j.1600-0889.2010.00501.x

Byrne, K.A., Kiely, G., 2006. Partitioning of Respiration in an Intensively Managed Grassland. Plant and Soil 282, 281-289. doi:10.1007/s11104-005-6065-z

Calanca, P., Vuichard, N., Campbell, C., Viovy, N., Cozic, A., Fuhrer, J., Soussana, J.F., 2007. Simulating the fluxes of $\mathrm{CO}_{2}$ and $\mathrm{N}_{2} \mathrm{O}$ in European grasslands with the Pasture Simulation Model (PaSim). Agriculture Ecosystems \& Environment 121, 164-174. doi: 10.1016/j.agee.2006.12.010

Campbell, G.S., 1985. Soil physics with BASIC: transport models for soil-plant systems. Elsevier, Amsterdam.

Cantarel, A.A.M., Bloor, J.M.G., Pommier, T., Guillaumaud, N., Moirot, C., Soussana, J.-F., Poly, F., 2012. Four years of experimental climate change modifies the microbial drivers of $\mathrm{N}_{2} \mathrm{O}$ fluxes in an upland grassland ecosystem. Global Change Biology 18, 2520-2531. doi:10.1111/j.1365-2486.2012.02692.x

Chang, J., Viovy, N., Vuichard, N., Ciais, P., Wang, T., Cozic, A., Lardy, R., Graux, A.-I., Klumpp, K., Martin, R., Soussana, J.-F., 2013. Incorporating grassland management in a global vegetation model: model description and evaluation at 11 eddy-covariance sites in 
Europe. Geoscientific Model Development Discussions 6, 2769-2812. doi:10.5194/gmdd-6-2769-2013

Chen, D.-X., Hunt, H.W., Morgan, J.A., 1996. Responses of a C3 and C4 perennial grass to $\mathrm{CO}_{2}$ enrichment and climate change: Comparison between model predictions and experimental data. Ecological Modelling 87, 11-27. doi:10.1016/0304-3800(94)00199-5

Chirinda, N., Kracher, D., Lægdsmand, M., Porter, J.R., Olesen, J.E., Petersen, B.M., Doltra, J., Kiese, R., Butterbach-Bahl, K., 2011. Simulating soil $\mathrm{N}_{2} \mathrm{O}$ emissions and heterotrophic $\mathrm{CO}_{2}$ respiration in arable systems using FASSET and MoBiLE-DNDC. Plant and Soil 343, 139-160. doi:10.1007/s11104-010-0596-7

Churkina, G., Running, S.W., Schloss, A.L., The Participants of the Potsdam NdP Model intercomparison, 1999. Comparing global models of terrestrial net primary productivity (NPP): the importance of water availability. Global Change Biology 5, 46-55. doi:10.1046/j.1365-2486.1999.00006.x

Ciais, P., Reichstein, M., Viovy, N., Granier, A., Ogée, J., Allard, V., Aubinet, M., Buchmann, N., Bernhofer, C., Carrara, A., Chevallier, F., De Noblet, N., Friend, A.D., Friedlingstein, P., Grünwald, T., Heinesch, B., Keronen, P., Knohl, A., Krinner, G., Loustau, D., Manca, G., Matteucci, G., Miglietta, F., Ourcival, J.M., Papale, D., Pilegaard, K., Rambal, S., Seufert, G., Soussana, J.F., Sanz, M.J., Schulze, E.D., Vesala, T., Valentini, R., 2005. Europe-wide reduction in primary productivity caused by the heat and drought in 2003 . Nature 437, 529-533. doi:10.1038/nature03972

Ciais, P., Sabine, C., Bala, G., Bopp, L., Brovkin, V., Canadell, J., Chhabra, A., DeFries, R., Galloway, J., Heimann, M., Jones, C., Le Quéré, C., Myneni, R.B., Piao S., Thornton, P., 2013. Carbon and other biogeochemical cycles. In: Stocker, T.F., Qin, D., Plattner, G.-K., Tignor, M., Allen, S.K., Boschung, J., Nauels, A., Xia, Y., Bex, V., Midgley, P.M. (Eds.), Climate Change 2013: The Physical Science Basis. Contribution of Working Group I to the Fifth Assessment Report of the Intergovernmental Panel on Climate Change. Cambridge University Press, Cambridge, pp. 465-570. <http://www.ipcc.ch/report/ar5/wg1>

Ciais, P., Soussana, J.F., Vuichard, N., Luyssaert, S., Don, A., Janssens, I.A., Piao, S.L., Dechow, R., Lathière, J., Maignan, F., Wattenbach, M., Smith, P., Ammann, C., Freibauer, A., Schulze, E.D., the CARBOEUROPE Synthesis Team, 2010. The greenhouse gas balance of European grasslands. Biogeosciences Discussions 7, 5997-6050. doi:10.5194/bgd-7-5997-2010

De Jager, J.M., 1994. Accuracy of vegetation evaporation ratio formulae for estimating final wheat yield. Water SA 20, 307-314.

De Martonne, E, 1942. Nouvelle carte mondiale de I'indice d'aridité. Annales de Géographie 51, 242-250 (in French).

Desai, A.R., Richardson, A.D., Moffat, A.M., Kattge, J., Hollinger, D.Y., Barr, A., Falge, E., Noormets, A., Papale, D., Reichstein, M., Stauch, V.J., 2008. Cross-site evaluation of eddy covariance GPP and RE decomposition techniques. Agricultural and Forest Meteorology 148, 821-838. doi:10.1016/j.agrformet.2007.11.012

Diodato, N., Ceccarelli, M., 2004. Multivariate indicator Kriging approach using a GIS to classify soil degradation for Mediterranean agricultural lands. Ecological Indicators 4, 177-187. doi:10.1016/j.ecolind.2004.03.002

Donatelli, M., Cerrani, I., Fanchini, D., Fumagalli, D., Rizzoli, A.E., 2012. Enhancing model reuse via 
component-centered modeling frameworks: the vision and example realizations. In: Seppelt, R., Voinov, A.A., Lange, S., Bankamp, D. (Eds.), Proceedings of International Congress on Environmental Modelling and Software Managing Resources of a Limited Planet, Sixth Biennial Meeting, Leipzig, Germany, pp. 1185-1192.

Duru, M., Jouany, C., Le Roux, X., Navas, M.L., Cruz, P., 2013. From a conceptual framework to an operational approach for managing grassland functional diversity to obtain targeted ecosystem services: Case studies from French mountains. Renewable Agriculture and Food Systems 23, 239-254. doi:10.1017/\$1742170513000306

EC, 2008. Regulation (EC) No 1166/2008 of the European Parliament and of the Council of 19 November 2008 on farm structure surveys and the survey on agricultural production methods and repealing Council Regulation (EEC). Official Journal of the European Union, Brussels.

Flechard, C.R., Ambus, P., Skiba, U., Rees, R.M., Hensen, A., van Amstel, A., Dasselaar, A. van den P., Soussana, J.F., Jones, M., Clifton-Brown, J., Raschi, A., Horvath, L., Neftel, A., Jocher, M., Ammann, C., Leifeld, J., Fuhrer, J., Calanca, P., Thalman, E., Pilegaard, K., Di Marco, C., Campbell, C., Nemitz, E., Hargreaves, K.J., Levy, P.E., Ball, B.C., Jones, S.K., van de Bulk, W.C.M., Groot, T., Blom, M., Domingues, R., Kasper, G., Allard, V., Ceschia, E., Cellier, P., Laville, P., Henault, C., Bizouard, F., Abdalla, M., Williams, M., Baronti, S., Berretti, F., Grosz, B., 2007. Effects of climate and management intensity on nitrous oxide emissions in grassland systems across Europe. Agriculture, Ecosystems \& Environment 121, 135-152. doi:10.1016/j.agee.2006.12.024

Fox, D.G., 1981. Judging air quality model performance. Bulletin of the American Meteorological Society 599-609. doi:http://dx.doi.org/10.1175/1520-0477(1981)062<0599:JAQMP>2.0.CO;2

Gilmanov, T.G., Aires, L., Barcza, Z., Baron, V.S., Belelli, L., Beringer, J., Billesbach, D., Bonal, D., Bradford, J., Ceschia, E., Cook, D., Corradi, C., Frank, A., Gianelle, D., Gimeno, C., Gruenwald, T., Guo, H., Hanan, N., Haszpra, L., Heilman, J., Jacobs, A., Jones, M.B., Johnson, D.A., Kiely, G., Li, S., Magliulo, V., Moors, E., Nagy, Z., Nasyrov, M., Owensby, C., Pinter, K., Pio, C., Reichstein, M., Sanz, M.J., Scott, R., Soussana, J.F., Stoy, P.C., Svejcar, T., Tuba, Z., Zhou, G., 2010. Productivity, respiration, and light-response parameters of world grassland and agroecosystems derived from flux-tower measurements. Rangeland Ecology \& Management 63, 16-39. doi:10.2111/REM-D-09-00072.1

Giraldo, L.M., Lizcano, L.J., Gijsman, A.J., Rivera, B., Franco, L.H., 1999. Adapting the CROPGRO model of DSSAT to simulate the growth of Brachiaria decumbens. In: Proceedings of The Third International Symposium on Systems Approaches for Agricultural Development. Lima, Peru, pp. 1-10.

Graux, A.-I., Bellocchi, G., Lardy, R., Soussana, J.-F., 2013. Ensemble modelling of climate change risks and opportunities for managed grasslands in France. Agricultural and Forest Meteorology 170, 114-131. doi:10.1016/j.agrformet.2012.06.010

Graux, A.I., Gaurut, M., Agabriel, J., Baumont, R., Delagarde, R., Delaby, L., Soussana, J.F., 2011. Development of the Pasture Simulation Model for assessing livestock production under climate change. Agriculture, Ecosystems \& Environment 144, 69-91. doi: 10.1016/j.agee.2011.07.001

Graux, A.-I., Lardy, R., Bellocchi, G., Soussana, J.-F., 2012. Global warming potential of French 
grassland-based dairy livestock systems under climate change. Regional Environmental Change 12, 751-763. doi:10.1007/s10113-012-0289-2

Hagen, S.C., Braswell, B.H., Linder, E., Frolking, S., Richardson, A.D., Hollinger, D.Y., 2006. Statistical uncertainty of eddy flux-based estimates of gross ecosystem carbon exchange at Howland Forest, Maine. Journal of Geophysical Research 111, D08S03. doi:10.1029/2005JD006154.

Hidy, D., Barcza, Z., Haszpra, L., Churkina, G., Pintér, K., Nagy, Z., 2012. Development of the Biome-BGC model for simulation of managed herbaceous ecosystems. Ecological Modelling 226, 99-119. doi:10.1016/j.ecolmodel.2011.11.008

Hollinger, D.Y., Richardson, A.D., 2005. Uncertainty in eddy covariance measurements and its application to physiological models. Tree Physiology 25, 873-885. doi:10.1093/treephys/25.7.873

Holzworth, D.P., Huth, N.I., deVoil, P.G., Zurcher, E.J., Herrmann, N.I., McLean, G., Chenu, K., van Oosterom, E., Snow, V.O., Murphy, C., Moore, A.D., Brown, H.E., Whish, J.P.M., Verrall, S., Fainges, J., L.W., B., Peake, A.S., Poulton, P.L., Hochman, Z., Thorburn, P.J., Gaydon, D.S., Dalgliesh, N.P., Rodriguez, D., Cox, H., Chapman, S., Doherty, A., Teixeira, E., Sharp, J., Cichota, R., Vogeler, I., Li, F.Y., Wang, E., Hammer, G.L., Robertson, M.J., Dimes, J., Carberry, P.S., Hargreaves, J.N.G., MacLeod, N., McDonald, C., Harsdorf, J., Wedgwood, S., Keating, B.A., 2014. APSIM - Evolution towards a new generation of agricultural systems simulation. Environmental Modelling \& Software, in press. doi:10.1016/j.envsoft.2014.07.009

Huntzinger, D.N., Post, W.M., Wei, Y., Michalak, A.M., West, T.O., Jacobson, A.R., Baker, I.T., Chen, J.M., Davis, K.J., Hayes, D.J., Hoffman, F.M., Jain, A.K., Liu, S., McGuire, A.D., Neilson, R.P., Potter, C., Poulter, B., Price, D., Raczka, B.M., Tian, H.Q., Thornton, P., Tomelleri, E., Viovy, N., Xiao, J., Yuan, W., Zeng, N., Zhao, M., Cook, R., 2012. North American Carbon Program (NACP) regional interim synthesis: Terrestrial biospheric model intercomparison. Ecological Modelling 232, 144-157. doi:10.1016/j.ecolmodel.2012.02.004

Hussain, M.Z., Gruenwald, T., Tenhunen, J.D., Li, Y.L., Mirzae, H., Bernhofer, C., Otieno, D., Dinh, N.Q., Schmidt, M., Wartinger, M., Owen, K., 2011. Summer drought influence on $\mathrm{CO}_{2}$ and water fluxes of extensively managed grassland in Germany. Agriculture, Ecosystems \& Environment 141, 67-76. doi:10.1016/j.agee.2011.02.013

Jacobs, C.M.J., Jacobs, A.F.G., Bosveld, F.C., Hendriks, D.M.D., Hensen, A., Kroon, P.S., Moors, E.J. Nol, L., Schrier-Uijl, A., Veenendaal, E.M., 2007. Variability of annual $\mathrm{CO}_{2}$ exchange from Dutch grasslands. Biogeosciences 4, 803-816.doi:10.5194/bg-4-803-2007

Janssens, I.A., Freibauer, A., Schlamadinger, B., Ceulemans, R., Ciais, P., Dolman, A.J., Heimann, M., Nabuurs, G.-J., Smith, P., Valentini, R., 2005. The carbon budget of terrestrial ecosystems at country-scale - a European case study. Biogeosciences 2, 15-26. doi:10.5194/bg-2-15-2005

Johnson, I.R., Chapman, D.F., Snow, V.O., Eckard, R.J., Parsons, A.J., Lambert, M.G., Cullen, B.R., 2008. DairyMod and EcoMod: biophysical pasture-simulation models for Australia and New Zealand. Australian Journal of Experimental Agriculture 48, 621-631. doi:10.1071/EA07133

Jung, M., Reichstein, M., Margolis, H.A., Cescatti, A., Richardson, A.D., Arain, M.A., Arneth, A., Bernhofer, C., Bonal, D., Chen, J., Gianelle, D., Gobron, N., Kiely, G., Kutsch, W., Lasslop, 
1035

1036

1037

1038

1039

1040

1041

1042

1043

1044

1045

1046

1047

1048

1049

1050

1051

1052

1053

1054

1055

1056

1057

1058

1059

1060

1061

1062

1063

1064

1065

1066

1067

1068

1069

1070

1071

1072

1073

1074

1075

1076

1077

1078

G., Law, B.E., Lindroth, A., Merbold, L., Montagnani, L., Moors, E.J., Papale, D., Sottocornola, M., Vaccari, F., Williams, C., 2011. Global patterns of land-atmosphere fluxes of carbon dioxide, latent heat, and sensible heat derived from eddy covariance, satellite, and meteorological observations. Journal of Geophysical Research 116, G00J07. doi:10.1029/2010JG001566

Jung, M., Vetter, M., Herold, M., Churkina, G., Reichstein, M., Zaehle, S., Ciais, P., Viovy, N., Bondeau, A., Chen, Y., Trusilova, K., Feser, F., Heimann, M., 2007. Uncertainties of modeling gross primary productivity over Europe: A systematic study on the effects of using different drivers and terrestrial biosphere models. Global Biogeochemical Cycles 21, GB4021. doi:10.1029/2006GB002915

Klumpp, K., Tallec, T., Guix, N., Soussana, J.-F., 2011. Long-term impacts of agricultural practices and climatic variability on carbon storage in a permanent pasture. Global Change Biology 17, 3534-3545. doi:10.1111/j.1365-2486.2011.02490.x

Krinner, G., Viovy, N., de Noblet-Ducoudré, N., Ogée, J., Polcher, J., Friedlingstein, P., Ciais, P., Sitch, S., Prentice, I.C., 2005. A dynamic global vegetation model for studies of the coupled atmosphere-biosphere system. Global Biogeochemical Cycles 19, GB1015. doi:10.1029/2003GB002199

Kroon, P.S., Hensen, A., Jonker, H.J.J., Ouwersloot, H.G., Vermeulen, A.T., Bosveld, F.C., 2009. Uncertainties in eddy covariance flux measurements assessed from $\mathrm{CH}_{4}$ and $\mathrm{N}_{2} \mathrm{O}$ observations. Agricultural and Forest Meteorology 150, 806-816. doi: 10.1016/j.agrformet.2009.08.008

Laniak, G.F., Olchin, G., Goodall, J., Voinov, A., Hill, M., Glynn, P., Whelan, G., Geller, G., Quinn, N., Blind, M., Peckham, S., Reaney, S., Gaber, N., Kennedy, R., Hughes, A., 2013. Integrated environmental modeling: A vision and roadmap for the future. Environmental Modelling \& Software 39, 3-23. doi:10.1016/j.envsoft.2012.09.006

Lardy, R., Bachelet, B., Bellocchi, G., Hill, D.R.C., 2014. Towards vulnerability minimization of grassland soil organic matter using metamodels. Environmental Modelling \& Software 52, 38-50. doi:10.1016/j.envsoft.2013.10.015

Lasslop, G., Reichstein, M., Kattge, J., Papale, D., 2008. Influences of observation errors in eddy flux data on inverse model parameter estimation. Biogeosciences 5, 1311-1324. doi:doi:10.5194/bg-5-1311-2008

Liu, M., He, H., Yu, G., Sun, X., Zhang, L., Han, S., Wang, H., Zhou, G., 2012. Uncertainty analysis in data processing on the estimation of net carbon exchanges at different forest ecosystems in China. Journal of Forest Research 17, 312-322. doi:10.1007/s10310-011-0323-0

Luo, G., Han, Q., Zhou, D., Li, L., Chen, X., Li, Y., Hu, Y., Li, B.L., 2012. Moderate grazing can promote aboveground primary production of grassland under water stress. Ecological Complexity 11, 126-136. doi:10.1016/j.ecocom.2012.04.004

Lobell, D.B., Burke, M.B., 2010. On the use of statistical models to predict crop yield responses to climate change. Agricultural and Forest Meteorology 150, 1443-1452. doi:10.1016/j.agrformet.2010.07.008

Martin, G., Martin-Clouaire, R., Rellier, J.P., Duru, M., 2011. A simulation framework for the design of grassland-based beef-cattle farms. Environmental Modelling \& Software 26, 371-385. doi:10.1016/j.envsoft.2010.10.002

Migliavacca, M., Reichstein, M., Richardson, A.D., Colombo, R., Sutton, M.A., Lasslop, G., 
Tomelleri, E., Wohlfahrt, G., Carvalhais, N., Cescatti, A., Mahecha, M.D., Montagnani, L., Papale, D., Zaehle, S., Arain, A., Arneth, A., Black, T.A., Carrara, A., Dore, S., Gianelle, D., Helfter, C., Hollinger, D., Kutsch, W.L., Lafleur, P.M., Nouvellon, Y., Rebmann, C., Da ROCHA, H.R., Rodeghiero, M., Roupsard, O., Sebastià, M.-T., Seufert, G., Soussana, J.-F., Van Der MOLEN, M.K., 2011. Semiempirical modeling of abiotic and biotic factors controlling ecosystem respiration across eddy covariance sites. Global Change Biology 17, 390-409. doi:10.1111/j.1365-2486.2010.02243.x

Minunno, F., Peltoniemi, M., Launiainen, S., Mäkelä, A., 2014. Integrating ecosystems measurements from multiple eddy-covariance sites to a simple model of ecosystem process - Are there possibilities for a uniform model calibration? Geophysical Research Abstracts 16, EGU2014-10706-3.

Monteith, J., 1965. Evaporation and environment. Symposium of the Society for Experimental Biology 19, 205-234.

Moriasi, D., Arnold, J., Van Liew, M., Bingner, R., Harmel, R., Veith, T., 2007. Model evaluation guidelines for systematic quantification of accuracy in watershed simulations. Transactions of the ASABE 50, 885-900.

Moyano, F.E., Vasilyeva, N., Bouckaert, L., Cook, F., Craine, J., Curiel Yuste, J., Don, A., Epron, D., Formanek, P., Franzluebbers, A., Ilstedt, U., Kätterer, T., Orchard, V., Reichstein, M., Rey, A., Ruamps, L., Subke, J.-A., Thomsen, I.K., Chenu, C., 2012. The moisture response of soil heterotrophic respiration: interaction with soil properties. Biogeosciences 9, 1173-1182. doi:10.5194/bg-9-1173-2012

Nash, J.E., Sutcliffe, J.V., 1970. River flow forecasting through conceptual models part I - A discussion of principles. Journal of Hydrology 10, 282-290. doi:10.1016/0022-1694(70)90255-6

Palosuo, T., Kersebaum, K.C., Angulo, C., Hlavinka, P., Moriondo, M., Olesen, J.E., Patil, R.H., Ruget, F., Rumbaur, C., Takac, J., Trnka, M., Bindi, M., caldag, B., Ewert, F., Ferrise, R., Mirschel, W., Saylan, L., Siska, B., Roeter, R., 2011. Simulation of winter wheat yield and its variability in different climates of Europe: A comparison of eight crop growth models. European Journal of Agronomy 35, 103-114. doi: 10.1016/j.eja.2011.05.001

Papale, D., Reichstein, M., Aubinet, M., Canfora, E., Bernhofer, C., Longdoz, B., Kutsch, W., Rambal, S., Valentini, R., Vesala, T., Yakir, D., 2006. Towards a standardized processing of net ecosystem exchange measured with eddy covariance technique: algorithms and uncertainty estimation. Biogeosciences 3, 571-583. doi:10.5194/bg-3-571-2006

Parton, W.J., 1988. Dynamics of C, N, P and S in grassland soils: a model. Biogeochemistry 5, 109-131. doi:10.1007/BF02180320

Parton, W.J., Morgan, J.A., Wang, G., Del Grosso, S., 2007. Projected ecosystem impact of the Prairie Heating and $\mathrm{CO}_{2}$ Enrichment experiment. New Phytologist 174, 823-834. doi:10.1111/j.1469-8137.2007.02052.x

Peichl, M., Carton, O., Kiely, G., 2012. Management and climate effects on carbon dioxide and energy exchanges in a maritime grassland. Agriculture, Ecosystems \& Environment 158, 132-146. doi:10.1016/j.agee.2012.06.001

Pintér, K., Barcza, Z., Balogh, J., Czóbel, S., Csintalan, Z., Tuba, Z., Nagy, Z., 2008. Interannual variability of grasslands' carbon balance depends on soil type. Community Ecology 9, 43-48. doi:10.1556/ComEc.9.2008.S.7 
1123

1124

1125

1126

1127

1128

1129

1130

1131

1132

1133

1134

1135

1136

1137

1138

1139

1140

1141

1142

1143

1144

1145

1146

1147

1148

1149

1150

1151

1152

1153

1154

1155

1156

1157

1158

1159

1160

1161

1162

1163

1164

1165

1166

Prescher, A.-K., Grünwald, T., Bernhofer, C., 2010. Land use regulates carbon budgets in eastern Germany: From NEE to NBP. Agricultural and Forest Meteorology 150, 1016-1025. doi:10.1016/j.agrformet.2010.03.008

Rafique, R., Peichl, M., Hennessy, D., Kiely, G., 2011. Evaluating management effects on nitrous oxide emissions from grasslands using the process-based DeNitrification-DeComposition (DNDC) model. Atmospheric Environment 45, 6029-6039. doi:10.1016/j.atmosenv.2011.07.046

Refsgaard, J.C., van der Sluijs, J.P., Højberg, A.L., Vanrolleghem, P.A., 2007. Uncertainty in the environmental modelling process - A framework and guidance. Environmental Modelling \& Software 22, 1543-1556. doi:10.1016/j.envsoft.2007.02.004

Reichstein, M., Bahn, M., Ciais, P., Frank, D., Mahecha, M.D., Seneviratne, S.I., Zscheischler, J., Beer, C., Buchmann, N., Frank, D.C., Papale, D., Rammig, A., Smith, P., Thonicke, K., van der Velde, M., Vicca, S., Walz, A., Wattenbach, M., 2013. Climate extremes and the carbon cycle. Nature 500, 287-295. doi:10.1038/nature12350

Reichstein, M., Falge, E., Baldocchi, D., Papale, D., Aubinet, M., Berbigier, P., Bernhofer, C., Buchmann, N., Gilmanov, T., Granier, A., Grünwald, T., Havrankova, K., Ilvesniemi, H., Janous, D., Knohl, A., Laurila, T., Lohila, A., Loustau, D., Matteucci, G., Meyers, T., Miglietta, F., Ourcival, J.-M., Pumpanen, J., Rambal, S., Rotenberg, E., Sanz, M., Tenhunen, J., Seufert, G., Vaccari, F., Vesala, T., Yakir, D., Valentini, R., 2005. On the separation of net ecosystem exchange into assimilation and ecosystem respiration: review and improved algorithm. Global Change Biology 11, 1424-1439. doi:10.1111/j.1365-2486.2005.001002.x

Richardson, A.D., Aubinet, M., Barr, A.G., Hollinger, D.Y., Ibrom, A., Lasslop, G., Reichstein, M., 2012, Uncertainty quantification. In: Aubinet, M., Vesala, T., Papale, D. (Eds.), Eddy covariance - A practical guide to measurement and data analysis. Springer, Dordrecht, pp. 173-209.

Richardson, A.D., Williams, M., Hollinger, D.Y., Moore, D.J.P., Dail, D.B., Davidson, E.A., Scott, N.A., Evans, R.S., Hughes, H., Lee, J.T., Rodrigues, C., Savage, K., 2010. Estimating parameters of a forest ecosystem $\mathrm{C}$ model with measurements of stocks and fluxes as joint constraints. Oecologia 164, 25-40. doi:10.1007/s00442-010-1628-y

Riedo, M., Grub, A., Rosset, M., Fuhrer, J., 1998. A pasture simulation model for dry matter production, and fluxes of carbon, nitrogen, water and energy. Ecological Modelling 105, 141-183. doi:10.1016/S0304-3800(97)00110-5

Riedo, M., Milford, C., Schmid, M., Sutton, M.A., 2002. Coupling soil-plant-atmosphere exchange of ammonia with ecosystem functioning in grasslands. Ecological Modelling 158, 83-110. doi:10.1016/S0304-3800(02)00169-2

Rodriguez, D., Van Oijen, M., Schapendonk, A., 1999. LINGRA-CC: a sink-source model to simulate the impact of climate change and management on grassland productivity. New Phytologist 144, 359-368. doi:10.1046/j.1469-8137.1999.00521.x

Rötter, R.P., Palosuo, T., Kersebaum, K.C., Angulo, C., Bindi, M., Ewert, F., Ferrise, R., Hlavinka, P., Moriondo, M., Nendel, C., Olesen, J.E., Patil, R.H., Ruget, F., Takac, J., Trnka, M., 2012. Simulation of spring barley yield in different climatic zones of Northern and Central Europe: A comparison of nine crop models. Field Crops Research 133, 23-36. doi:10.1016/j.fcr.2012.03.016 
1167

1168

1169

1170

1171

1172

1173

1174

1175

1176

1177

1178

1179

1180

1181

1182

1183

1184

1185

1186

1187

1188

1189

1190

1191

1192

1193

1194

1195

1196

1197

1198

1199

1200

1201

1202

1203

1204

1205

1206

1207

1208

1209

1210

Ruget, F., Satger, S., Volaire, F., Lelièvre, F., 2009. Modeling tiller density, growth, and yield of Mediterranean perennial grasslands with STICS. Crop Science 49, 2379-2385. doi:doi:10.2135/cropsci2009.06.0323

Schaefer, K., Schwalm, C.R., Williams, C., Arain, M.A., Barr, A., Chen, J.M., Davis, K.J., Dimitrov, D., Hilton, T.W., Hollinger, D.Y., Humphreys, E., Poulter, B., Raczka, B.M., Richardson, A.D., Sahoo, A., Thornton, P., Vargas, R., Verbeeck, H., Anderson, R., Baker, I., Black, T.A., Bolstad, P., Chen, J., Curtis, P.S., Desai, A.R., Dietze, M., Dragoni, D., Gough, C., Grant, R.F., Gu, L., Jain, A., Kucharik, C., Law, B., Liu, S., Lokipitiya, E., Margolis, H.A., Matamala, R., McCaughey, J.H., Monson, R., Munger, J.W., Oechel, W., Peng, C., Price, D.T., Ricciuto, D., Riley, W.J., Roulet, N., Tian, H., Tonitto, C., Torn, M., Weng, E., Zhou, X., 2012. A model-data comparison of gross primary productivity: Results from the North American Carbon Program site synthesis. Journal of Geophysical Research 117, G03010. doi:10.1029/2012JG001960

Schapendonk, A.H.C.M., Stol, W., van Kraalingen, D.W.G., Bouman, B.A.M., 1998. LINGRA, a sink/source model to simulate grassland productivity in Europe. European Journal of Agronomy 9, 87-100. doi:10.1016/S1161-0301(98)00027-6

Schmid, M., Fuhrer, J., Neftel, A., 2001a. Nitrous oxide concentrations in the soil of a mown grassland: comparison of model results with soil profile measurements. Water, Air, \& Soil Pollution: Focus 1, 437-446. doi:10.1023/A:1013158028103

Schmid, M., Neftel, A., Riedo, M., Fuhrer, J., 2001b. Process-based modelling of nitrous oxide emissions from different nitrogen sources in mown grassland. Nutrient Cycling in Agroecosystems 60, 177-187. doi:10.1023/a:1012694218748

Schmitt, M., Bahn, M., Wohlfahrt, G., Tappeiner, U., Cernusca, A., 2010. Land use affects the net ecosystem $\mathrm{CO}_{2}$ exchange and its components in mountain grasslands. Biogeosciences 7 , 2297-2309. doi:10.5194/bg-7-2297-2010

Schulze, E.D., Luyssaert, S., Ciais, P., Freibauer, A., Al, I.A.J. et, Schulze, E.D., Soussana, J.F., Smith, P., Grace, J., Levin, I., Thiruchittampalam, B., Heimann, M., Dolman, A.J., Valentini, R., Bousquet, P., Peylin, P., Peters, W., Rödenbeck, C., Etiope, G., Vuichard, N., Wattenbach, M., Nabuurs, G.J., Poussi, Z., Nieschulze, J., Gash, J.H., Schulze, E.D., Soussana, J.F., Smith, P., Grace, J., Levin, I., Thiruchittampalam, B., Heimann, M., Dolman, A.J., Valentini, R., Bousquet, P., Peylin, P., Peters, W., Rödenbeck, C., Etiope, G., Vuichard, N., Wattenbach, M., Nabuurs, G.J., Poussi, Z., Nieschulze, J., Gash, J.H., 2009. Importance of methane and nitrous oxide for Europe's terrestrial greenhouse-gas balance. Nature Geoscience 2, 842-850. doi:10.1038/ngeo686

Scurlock, J.M.O., Hall, D.O., 1998. The global carbon sink: a grassland perspective. Global Change Biology 4, 229-233. doi:10.1046/j.1365-2486.1998.00151.x

Sheikh, V., Visser, S., Stroosnijder, L., 2009. A simple model to predict soil moisture: Bridging Event and Continuous Hydrological (BEACH) modelling. Environmental Modelling \& Software 24, 542-556. doi:10.1016/j.envsoft.2008.10.005

Shuttleworth, W.J., Wallace, J.S., 1985. Evaporation from sparse crops-an energy combination theory. Quarterly Journal of the Royal Meteorological Society 111, 839-855. doi:10.1002/qj.49711146910

Snow, V.O., Rotz, C.A., Moore, A.D., Martin-Clouaire, R., Johnson, I.R., Hutchings, N.J., Eckard, R.J., 2014. The challenges - and some solutions - to process-based modelling of grazed 
1211

1212

1213

1214

1215

1216

1217

1218

1219

1220

1221

1222

1223

1224

1225

1226

1227

1228

1229

1230

1231

1232

1233

1234

1235

1236

1237

1238

1239

1240

1241

1242

1243

1244

1245

1246

1247

1248

1249

1250

1251

1252

1253

1254

agricultural systems. Environmental Modelling \& Software, 62, 420-436. doi:10.1016/j.envsoft.2014.03.009

Soussana, J.-F., Fuhrer, J., Jones, M., Van Amstel, A., 2007. The greenhouse gas balance of grasslands in Europe. Agriculture, Ecosystems \& Environment 121, 1-4. doi:10.1016/j.agee.2006.12.001

Stöckle, C.O., Donatelli, M., Nelson, R., 2003. CropSyst, a cropping systems simulation model. European Journal of Agronomy 18, 289-307. doi:10.1016/S1161-0301(02)00109-0

Suttie, J.M., Reynolds, S.G., Batello, C., 2005. Grasslands of the world. Food and Agricultural Organization of the United Nations, Rome.

Suttle, K.B., Thomsen, M.A., Power, M.E., 2007. Species interactions reverse grassland responses to changing climate. Science 315, 640-642. doi:10.1126/science.1136401

Thornley, J.H.M., 1998. Dynamic model of leaf photosynthesis with acclimation to light and nitrogen. Annals of Botany 81, 421-430. doi:10.1006/anbo.1997.0575

Trudinger, C.M., Raupach, M.R., Rayner, P.J., Kattge, J., Liu, Q., Pak, B., Reichstein, M., Renzullo, L., Richardson, A.D., Roxburgh, S.H., Styles, J., Wang, Y.P., Briggs, P., Barrett, D., Nikolova, S., 2007. OptIC project: An intercomparison of optimization techniques for parameter estimation in terrestrial biogeochemical models. Journal of Geophysical Research 112. doi:10.1029/2006JG000367

Van Oijen, M., Cameron, D.R., Butterbach-Bahl, K., Farahbakhshazad, N., Jansson, P.-E., Kiese, R., Rahn, K.-H., Werner, C., Yeluripati, J.B., 2011. A Bayesian framework for model calibration, comparison and analysis: Application to four models for the biogeochemistry of a Norway spruce forest. Agricultural and Forest Meteorology 151, 1609-1621. doi:10.1016/j.agrformet.2011.06.017

Van Oijen, M., Höglind, M., Hanslin, H.M., Caldwell, N., 2005. Process-based modeling of timothy regrowth. Agronomy Journal 97, 1295-1303. doi:10.2134/agronj2004.0251

Vital, J.-A., Gaurut, M., Lardy, R., Viovy, N., Soussana, J.-F., Bellocchi, G., Martin, R., 2013. High-performance computing for climate change impact studies with the Pasture Simulation model. Computers and Electronics in Agriculture 98, 131-135. doi:10.1016/j.compag.2013.08.004

Vuichard, N., Ciais, P., Viovy, N., Calanca, P., Soussana, J.-F., 2007a. Estimating the greenhouse gas fluxes of European grasslands with a process-based model: 2. Simulations at the continental level. Global Biogeochemical Cycles 21, GB1005. doi:10.1029/2005gb002612

Vuichard, N., Soussana, J.-F., Ciais, P., Viovy, N., Ammann, C., Calanca, P., Clifton-Brown, J., Fuhrer, J., Jones, M., Martin, C., 2007b. Estimating the greenhouse gas fluxes of European grasslands with a process-based model: 1 . Model evaluation from in situ measurements. Global Biogeochemical Cycles 21, GB1004. doi:10.1029/2005gb002611

Wallach, D., Thorburn, P.J., 2014. The error in agricultural systems model prediction depends on the variable being predicted. Environmental Modelling \& Software 62, 487-494. doi: 10.1016/j.envsoft.2014.08.001

Wang, J., Cardenas, L.M., Misselbrook, T.H., Cuttle, S., Thorman, R.E., Li, C., 2012. Modelling nitrous oxide emissions from grazed grassland systems. Environmental Pollution 162, 223-233.doi:10.1016/j.envpol.2011.11.027

Wang, Y.-P., Trudinger, C.M., Enting, I.G., 2009. A review of applications of model-data fusion to studies of terrestrial carbon fluxes at different scales. Agricultural and Forest 
Warmink, J.J., Janssen, J.A.E.B., Booij, M.J., Krol, M.S., 2010. Identification and classification of uncertainties in the application of environmental models. Environmental Modelling \& Software 25, 1518-1527. doi:10.1016/j.envsoft.2010.04.011

Warnant, P., François, L., Strivay, D., Gérard, J.C., 1994. CARAIB: A global model of terrestrial biological productivity. Global Biogeochemical Cycles 8, 255-270. doi:10.1029/94gb00850

Warszawski, L., Frieler, K., Huber, V., Piontek, F., Serdeczny, O., Schewe, J., 2014. The Inter-Sectoral Impact Model Intercomparison Project (ISI-MIP): Project framework. Proceedings of the National Academy of Sciences 111, 3228-3232. doi:10.1073/pnas.1312330110

Wattenbach, M., Sus, O., Vuichard, N., Lehuger, S., Gottschalk, P., Li, L., Leip, A., Williams, M., Tomelleri, E., Kutsch, W.L., Buchmann, N., Eugster, W., Dietiker, D., Aubinet, M., Ceschia, E., Béziat, P., Grünwald, T., Hastings, A., Osborne, B., Ciais, P., Cellier, P., Smith, P., 2010. The carbon balance of European croplands: A cross-site comparison of simulation models. Agriculture, Ecosystems \& Environment 139, 419-453.doi:10.1016/j.agee.2010.08.004

Wieder, W.R., Bonan, G.B., Allison, S.D., 2013. Global soil carbon projections are improved by modelling microbial processes. Nature Climate Change 3, 909-912. doi:10.1038/nclimate1951

Williams, J.R., Jones, C.A., Kiniry, J.R., Spanel, D.A., 1989. The EPIC crop growth model. Transactions of the ASAE 32, 497-511. doi:10.13031/2013.31032

Willmott, C.J., Wicks, D.E., 1980. An Empirical Method for the Spatial Interpolation of Monthly Precipitation within California. Physical Geography 1, 59-73. doi:10.1080/02723646.1980.10642189

Wohlfahrt, G., Anderson-Dunn, M., Bahn, M., Balzarolo, M., Berninger, F., Campbell, C., Carrara, A., Cescatti, A., Christensen, T., Dore, S., Eugster, W., Friborg, T., Furger, M., Gianelle, D., Gimeno, C., Hargreaves, K., Hari, P., Haslwanter, A., Johansson, T., Marcolla, B., Milford, C., Nagy, Z., Nemitz, E., Rogiers, N., Sanz, M.J., Siegwolf, R.T.W., Susiluoto, S., Sutton, M., Tuba, Z., Ugolini, F., Valentini, R., Zorer, R., Cernusca, A., 2008. Biotic, abiotic, and management controls on the net ecosystem $\mathrm{CO}_{2}$ exchange of European mountain grassland ecosystems. Ecosystems 11, 1338-1351. doi:10.1007/s10021-008-9196-2

Wu, J., van der Linden, L., Lasslop, G., Carvalhais, N., Pilegaard, K., Beier, C., Ibrom, A., 2012. Effects of climate variability and functional changes on the interannual variation of the carbon balance in a temperate deciduous forest. Biogeosciences 9, 13-28. doi:10.5194/bg-9-13-2012

Xiao, J., Chen, J., Davis, K.J., Reichstein, M., 2012. Advances in upscaling of eddy covariance measurements of carbon and water fluxes. Journal of Geophysical Research 117, G00J01. doi:10.1029/2011JG001889

Xiao, J., Zhuang, Q., Liang, E., Shao, X., McGuire, A.D., Moody, A., Kicklighter, D.W., Melillo, J.M., 2009. Twentieth-century droughts and their impacts on terrestrial carbon cycling in China. Earth Interactions 13, 1-31. doi:10.1175/2009EI275.1

Zeeman, M.J., Hiller, R., Gilgen, A.K., Michna, P., Plüss, P., Buchmann, N., Eugster, W., 2010. Management and climate impacts on net $\mathrm{CO}_{2}$ fluxes and carbon budgets of three grasslands along an elevational gradient in Switzerland. Agricultural and Forest 
50

51

52

55

56

57

58

59

60

61 


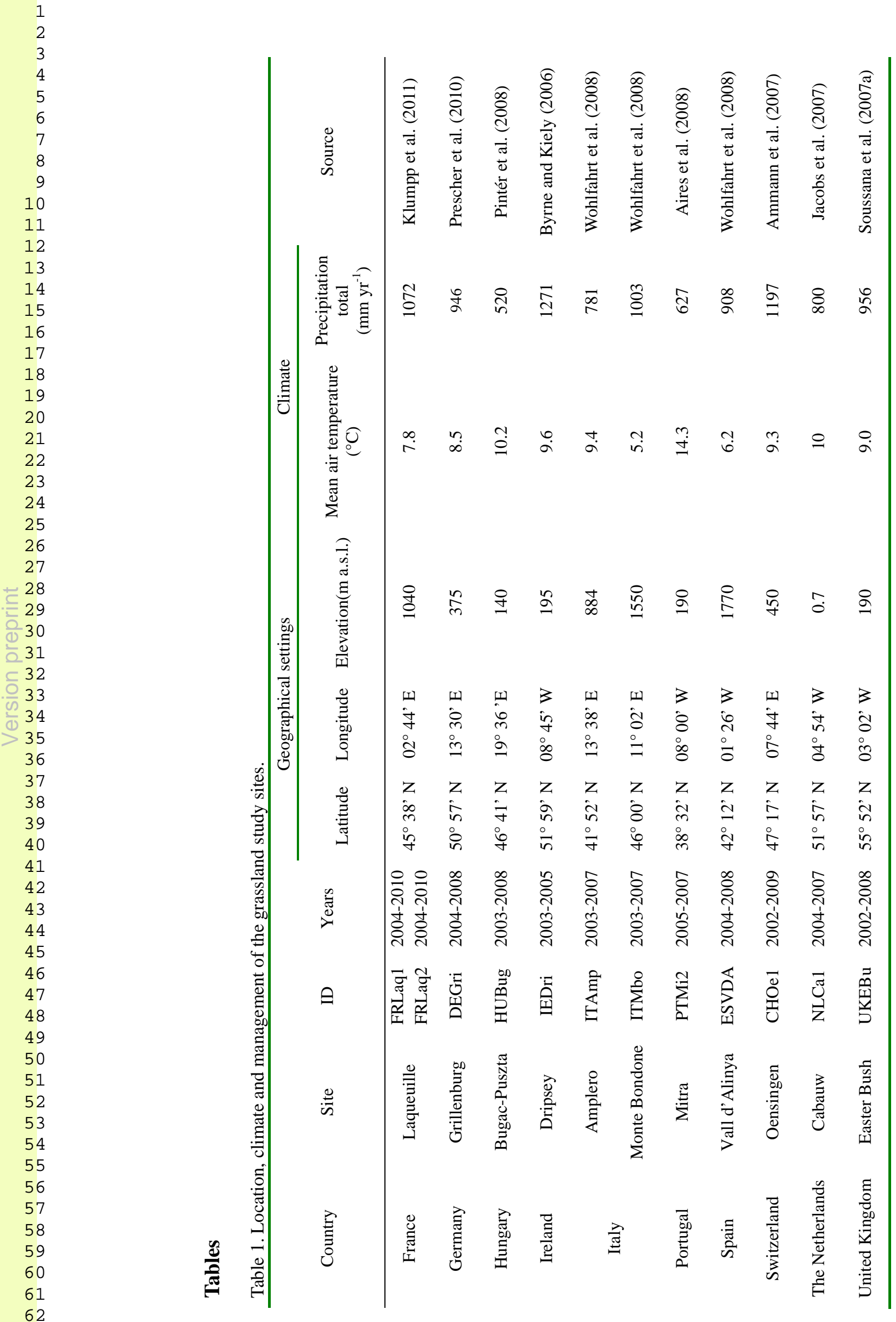




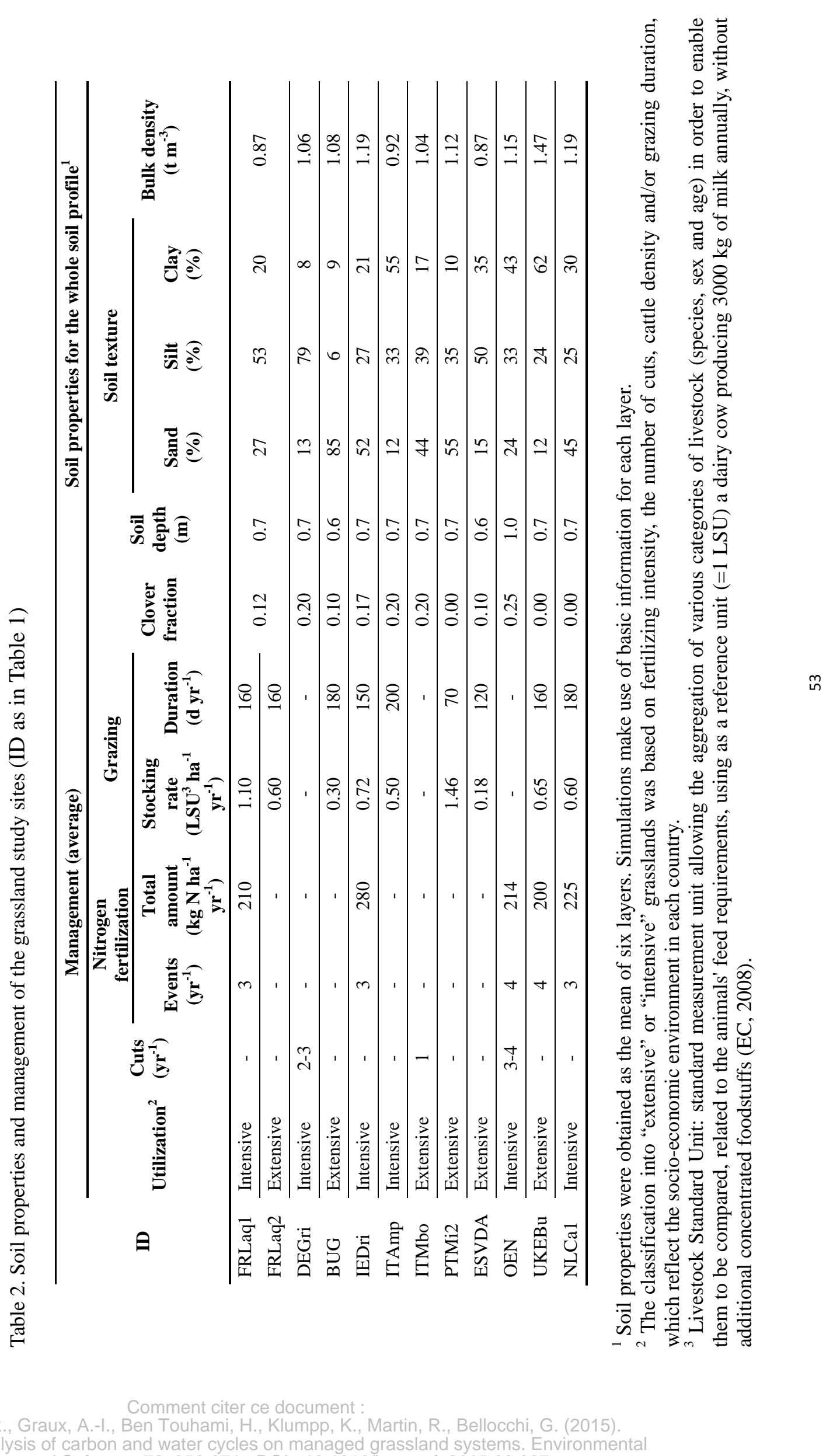




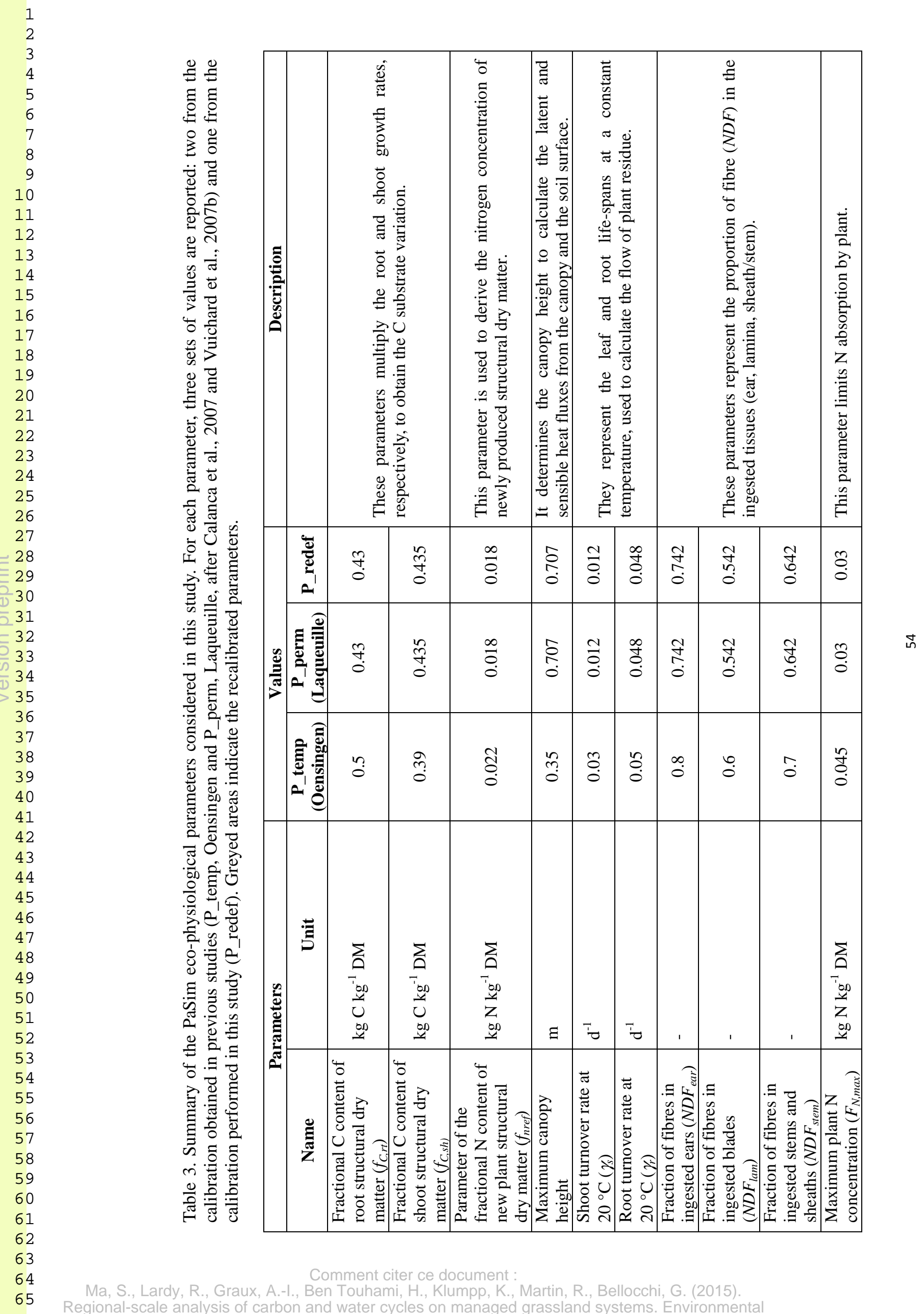




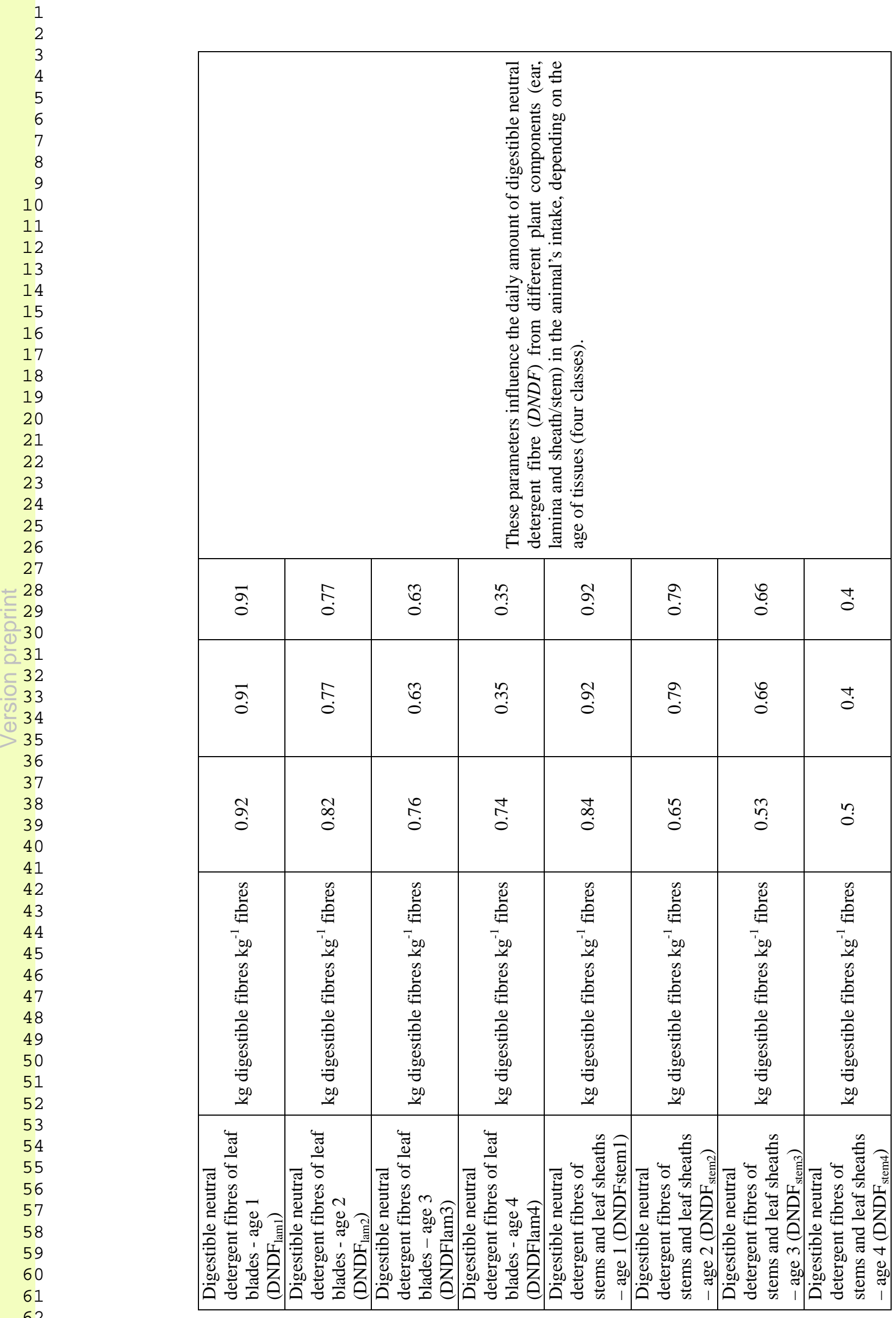




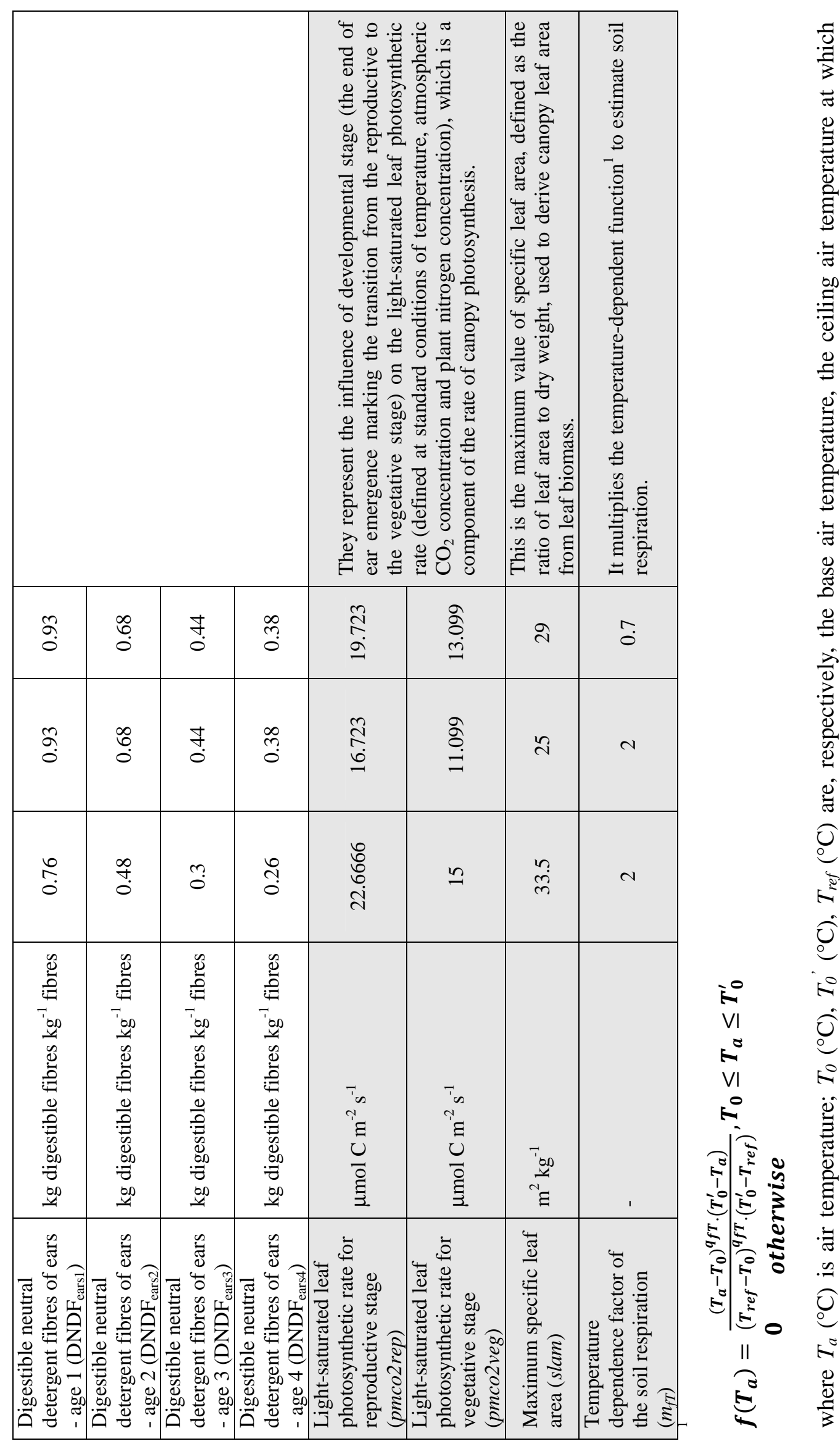




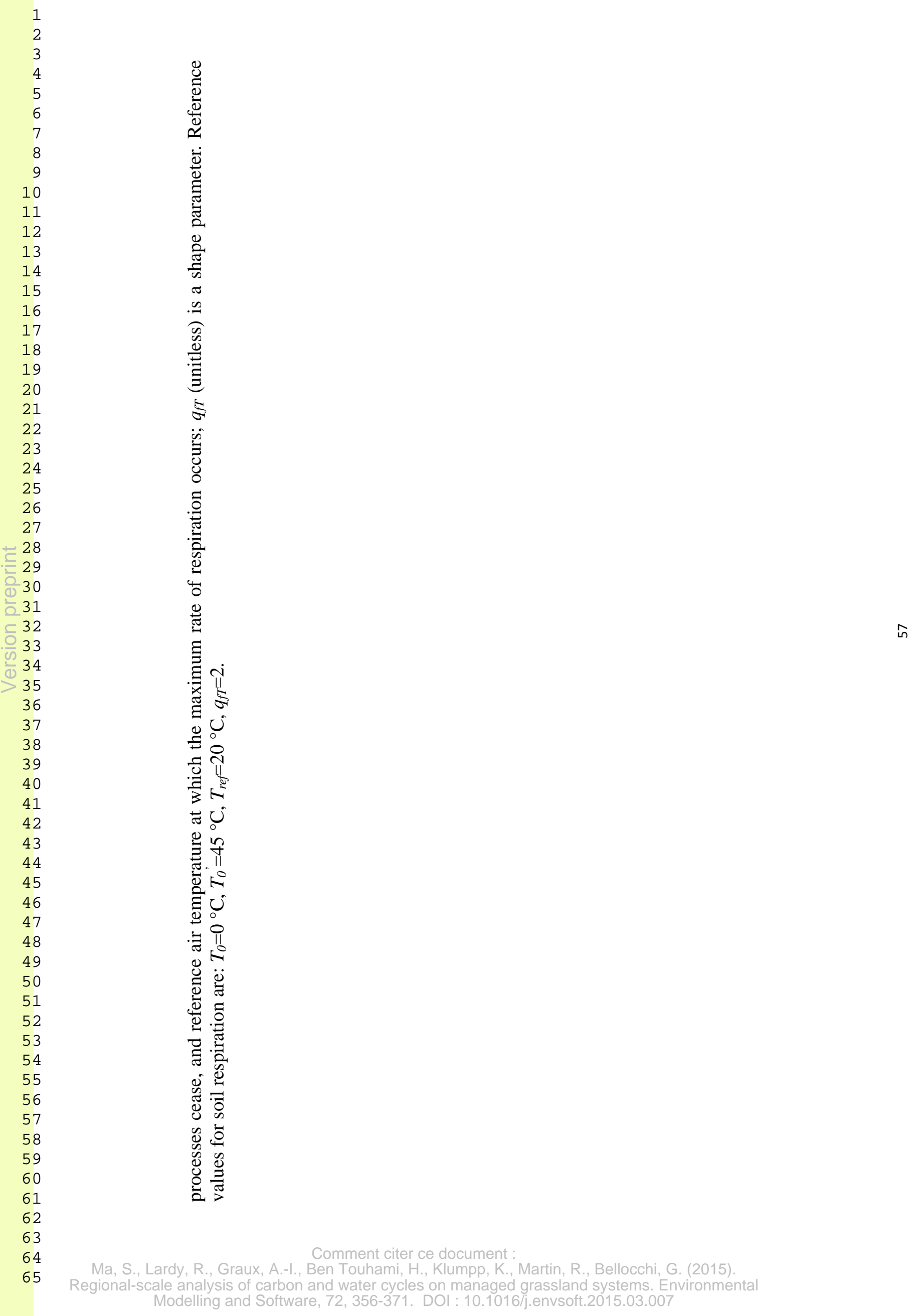




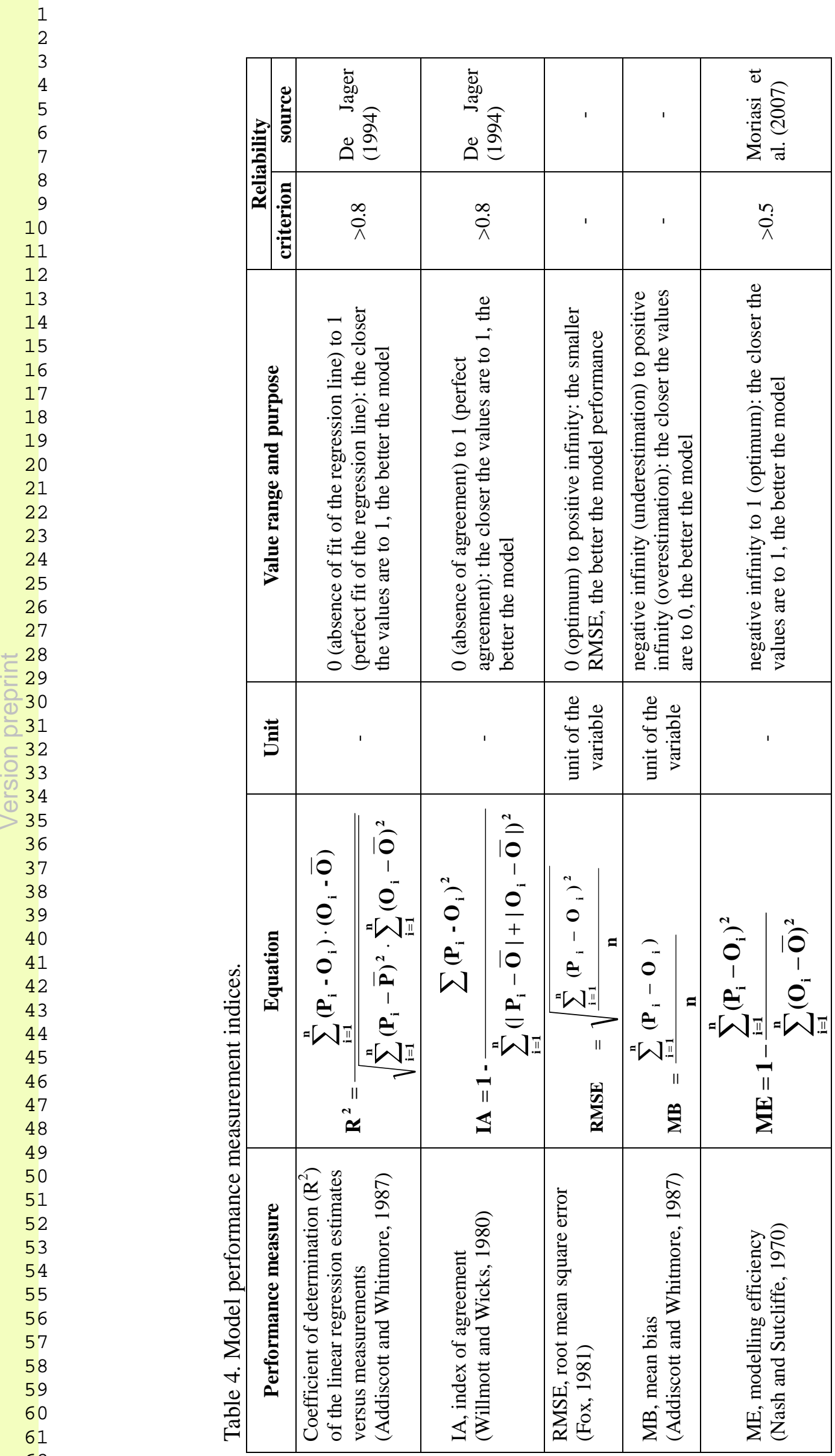




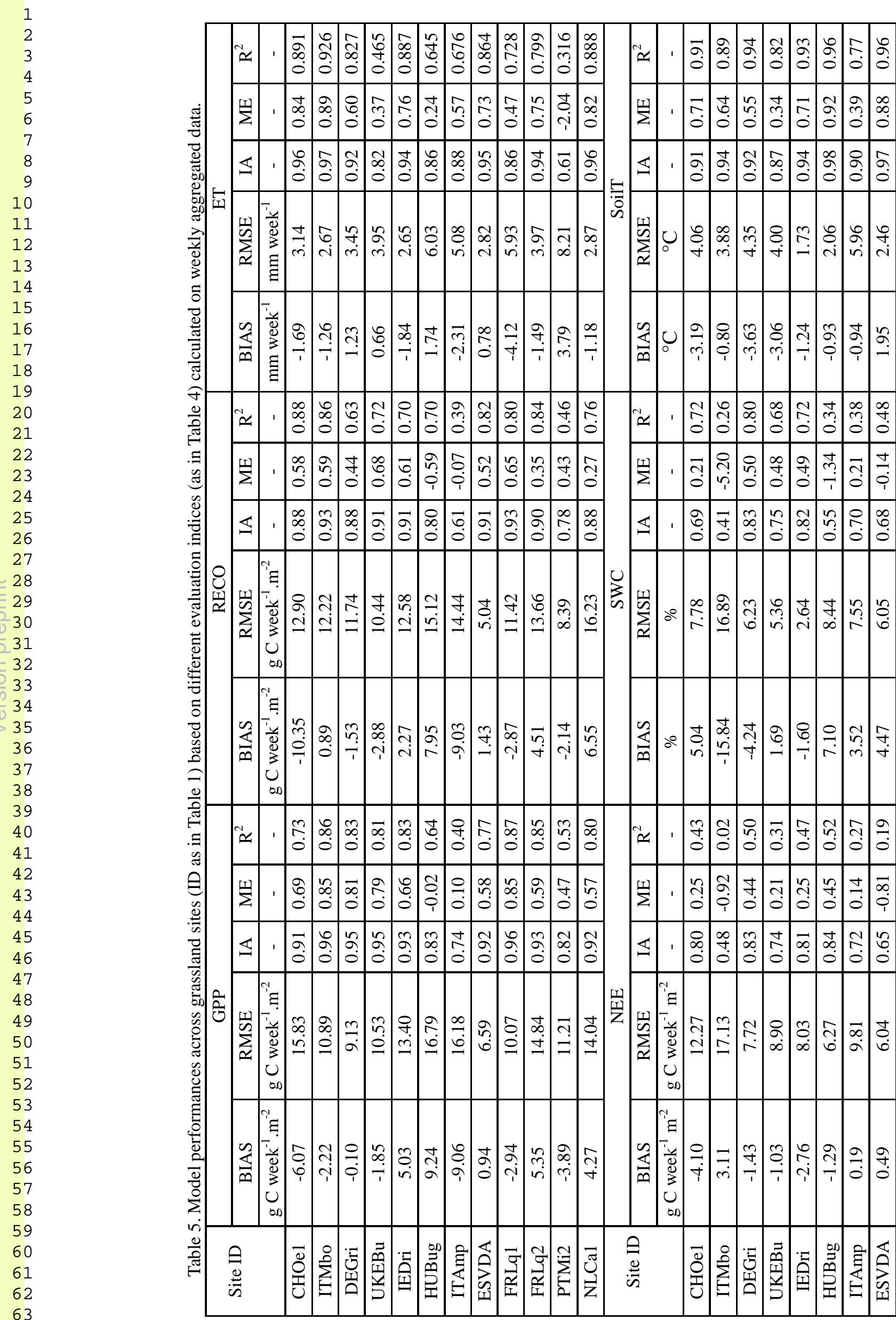




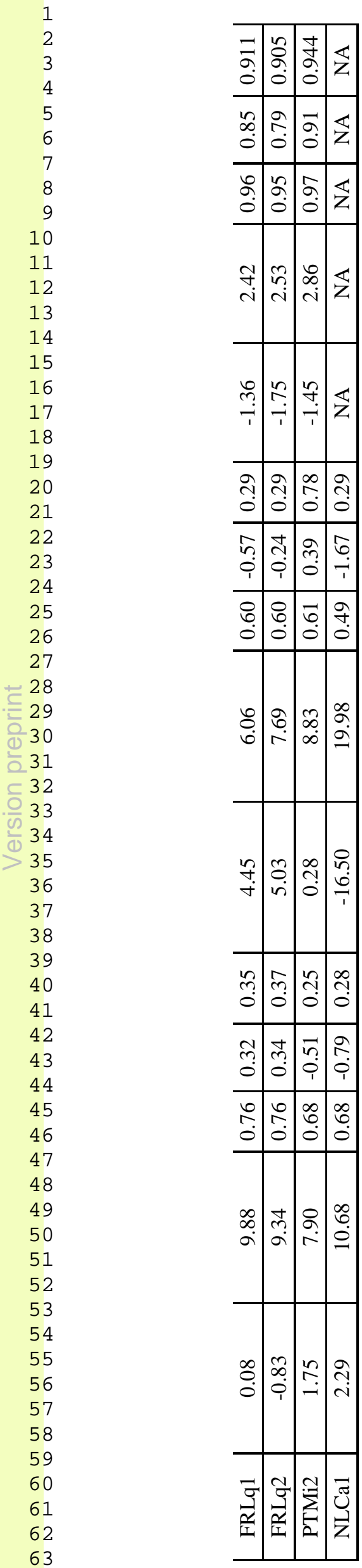




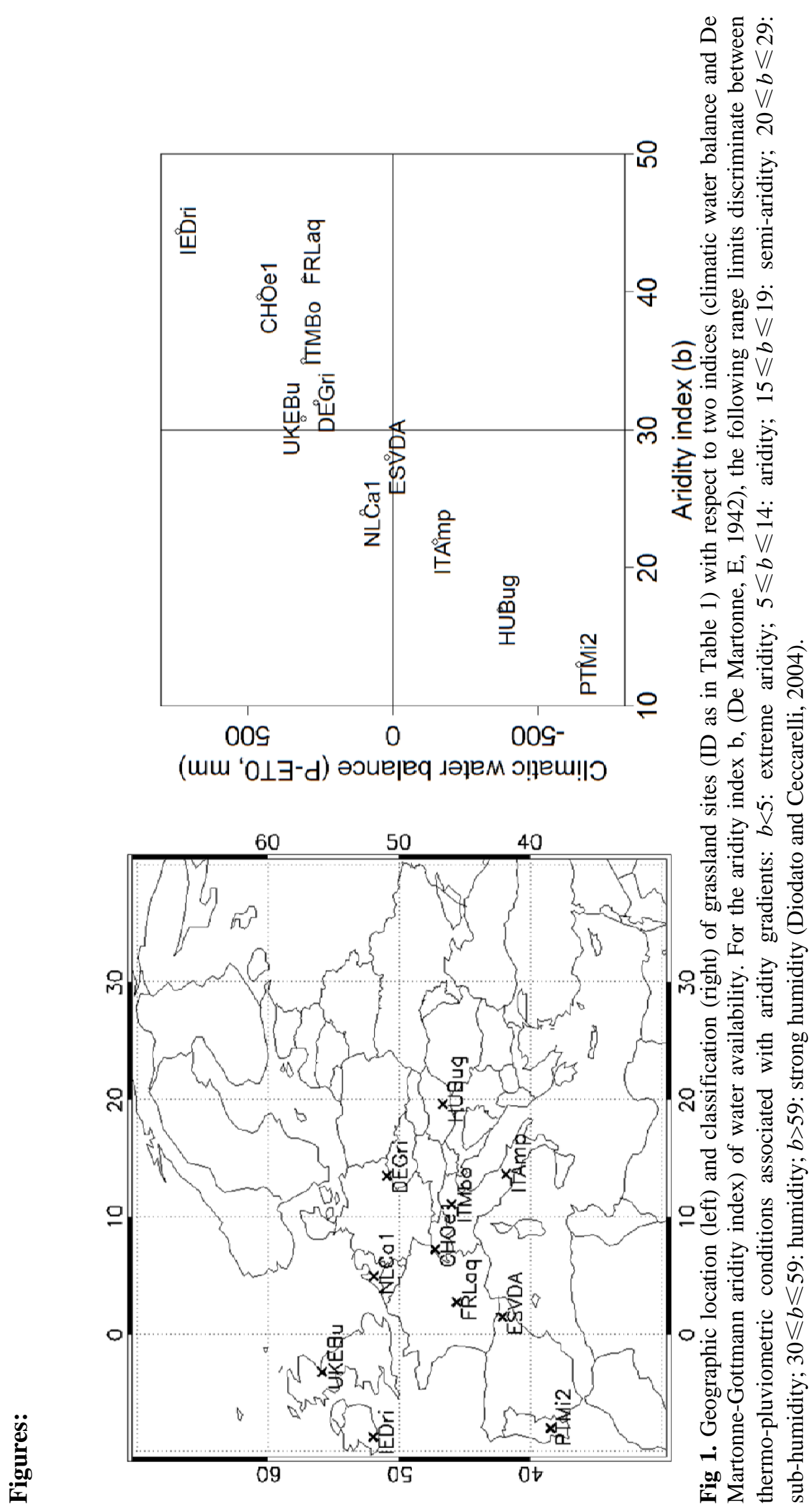




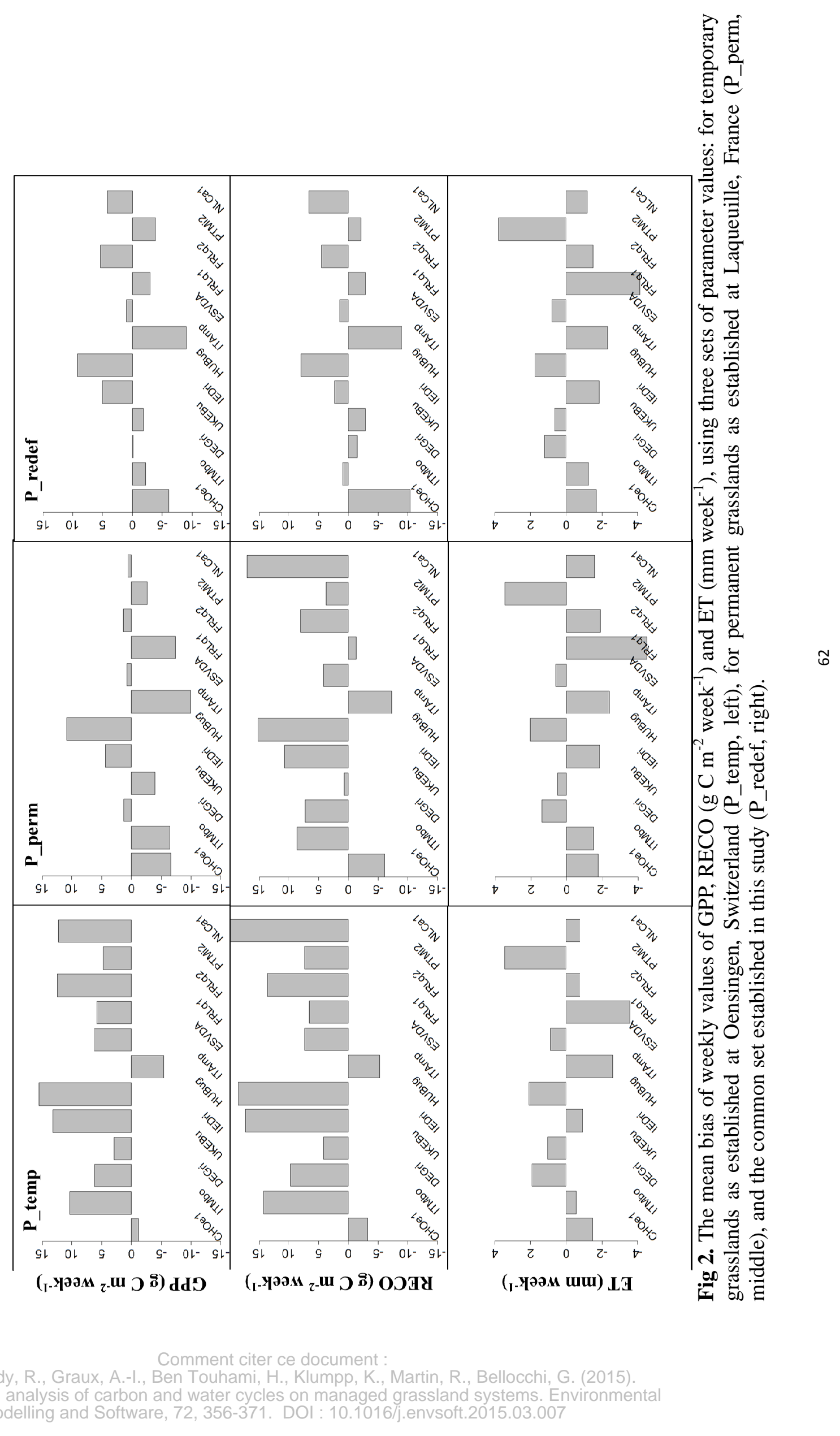



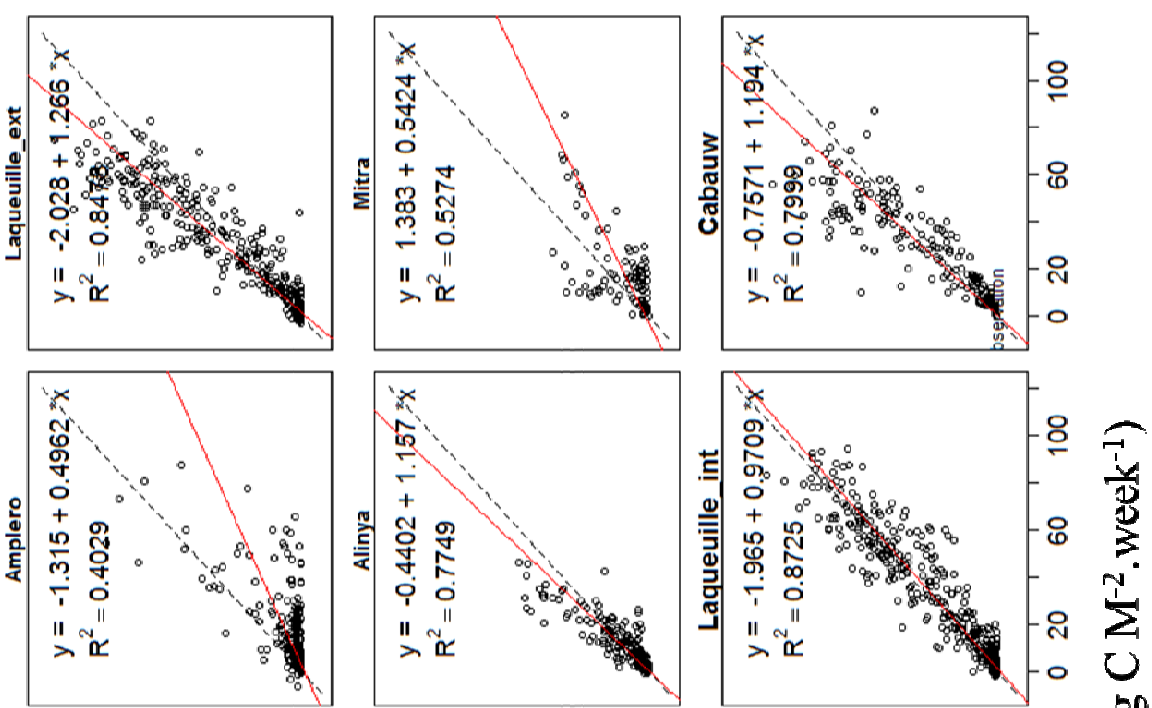

ஜ
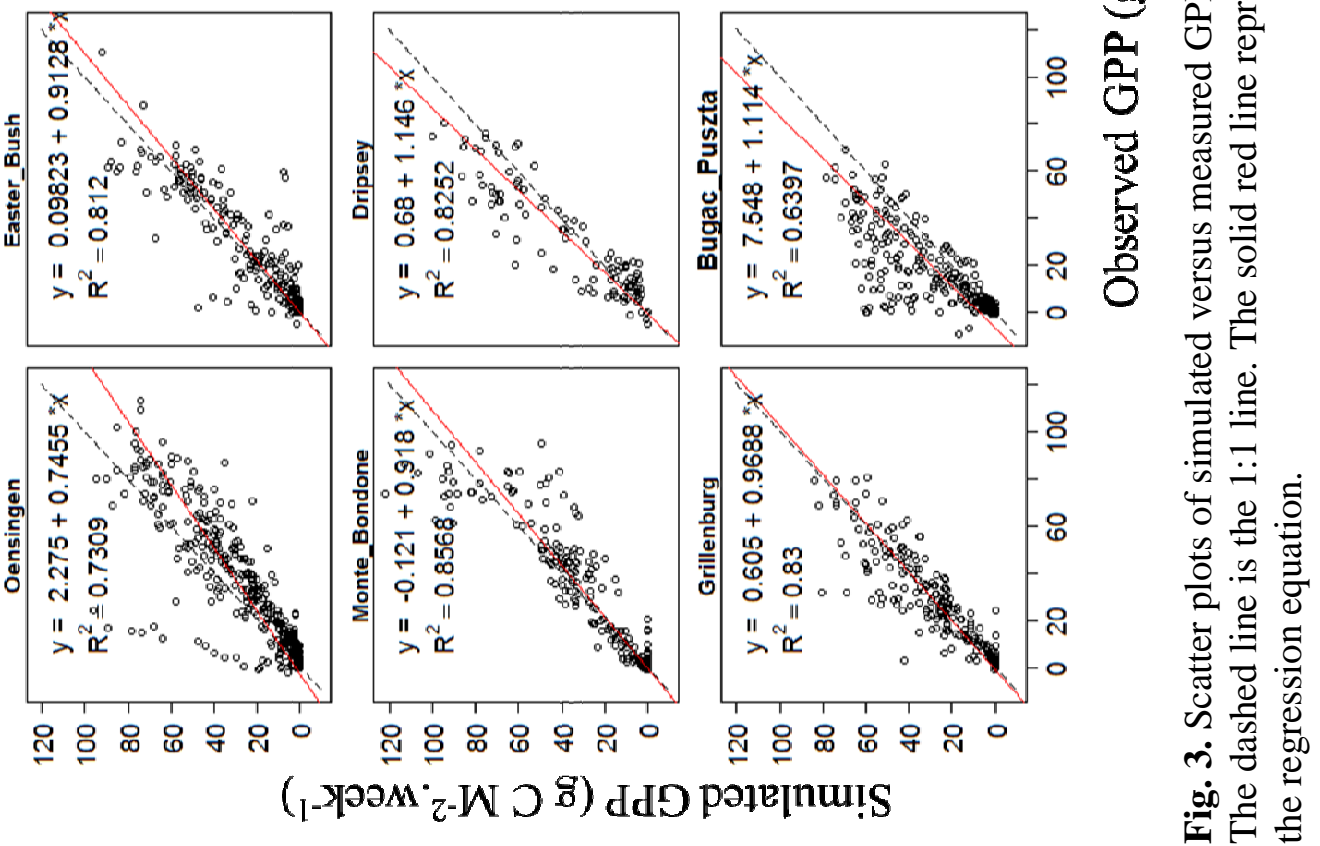

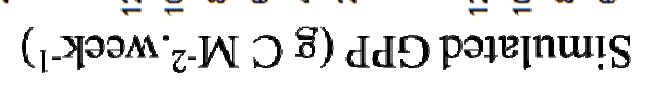

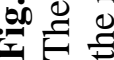



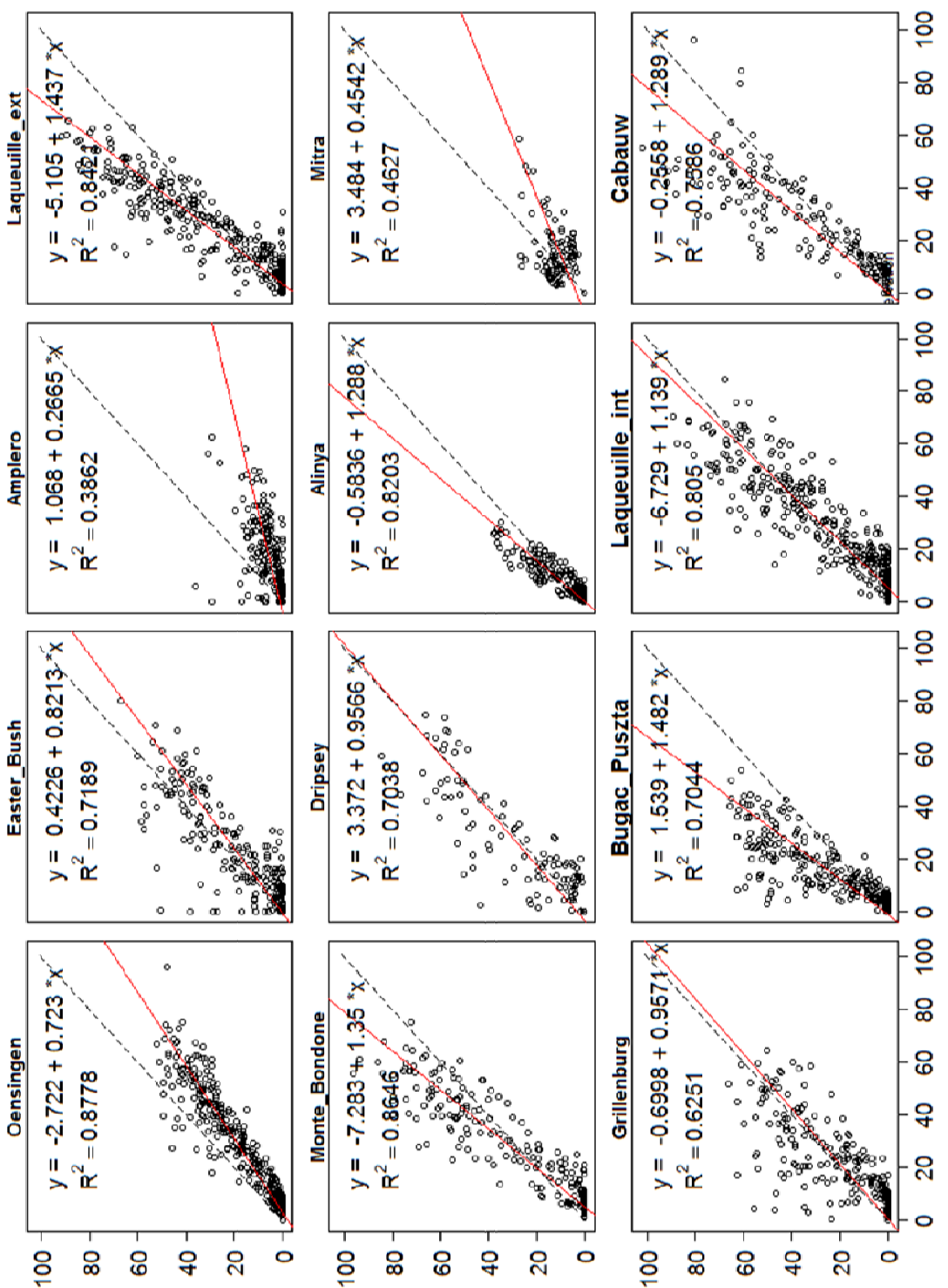

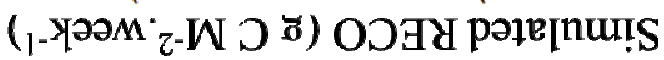

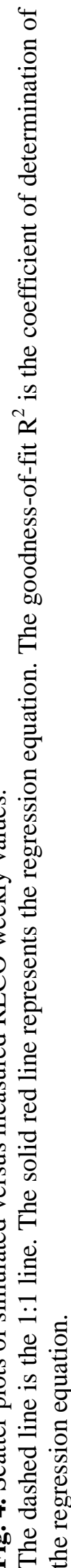




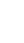

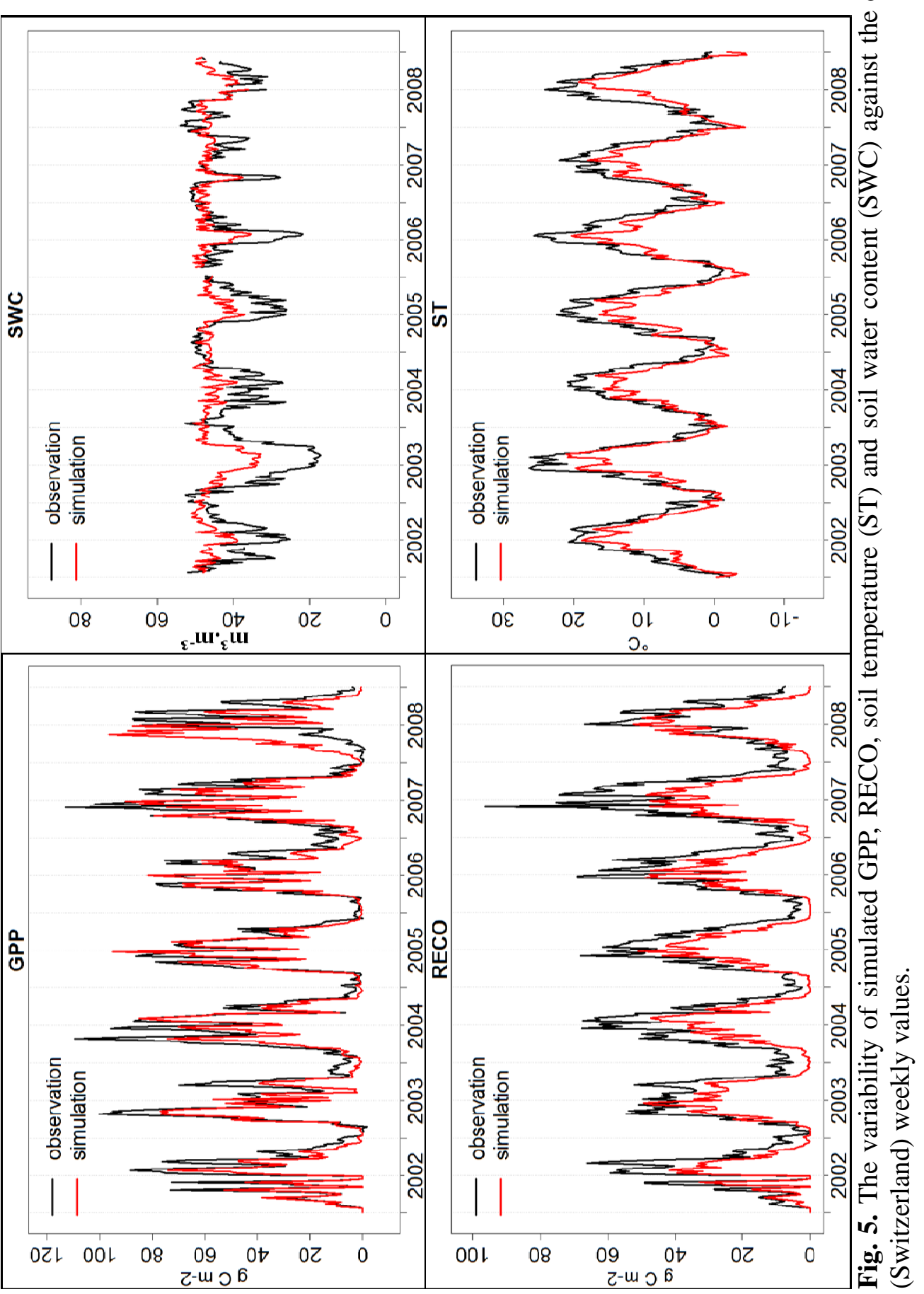




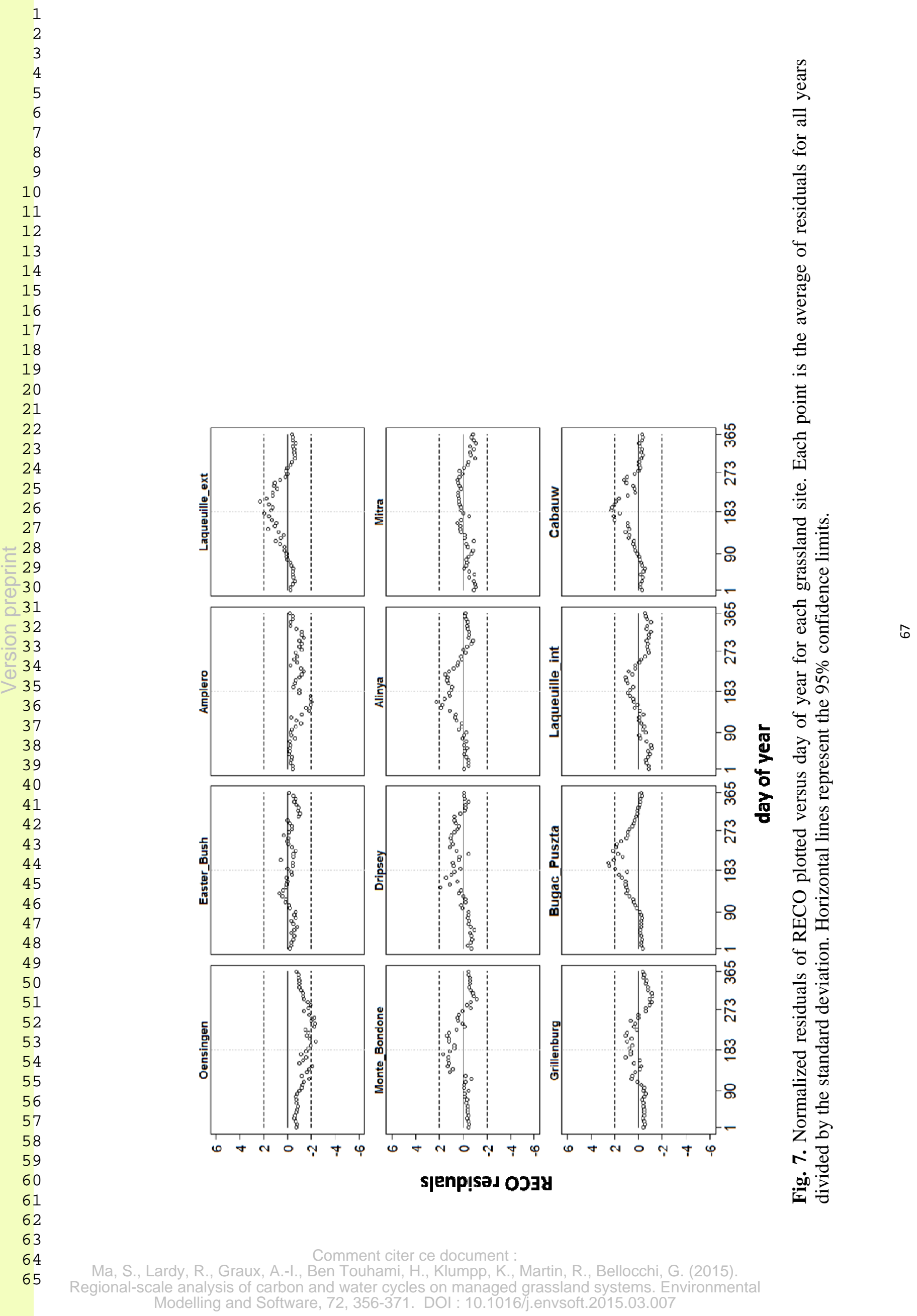




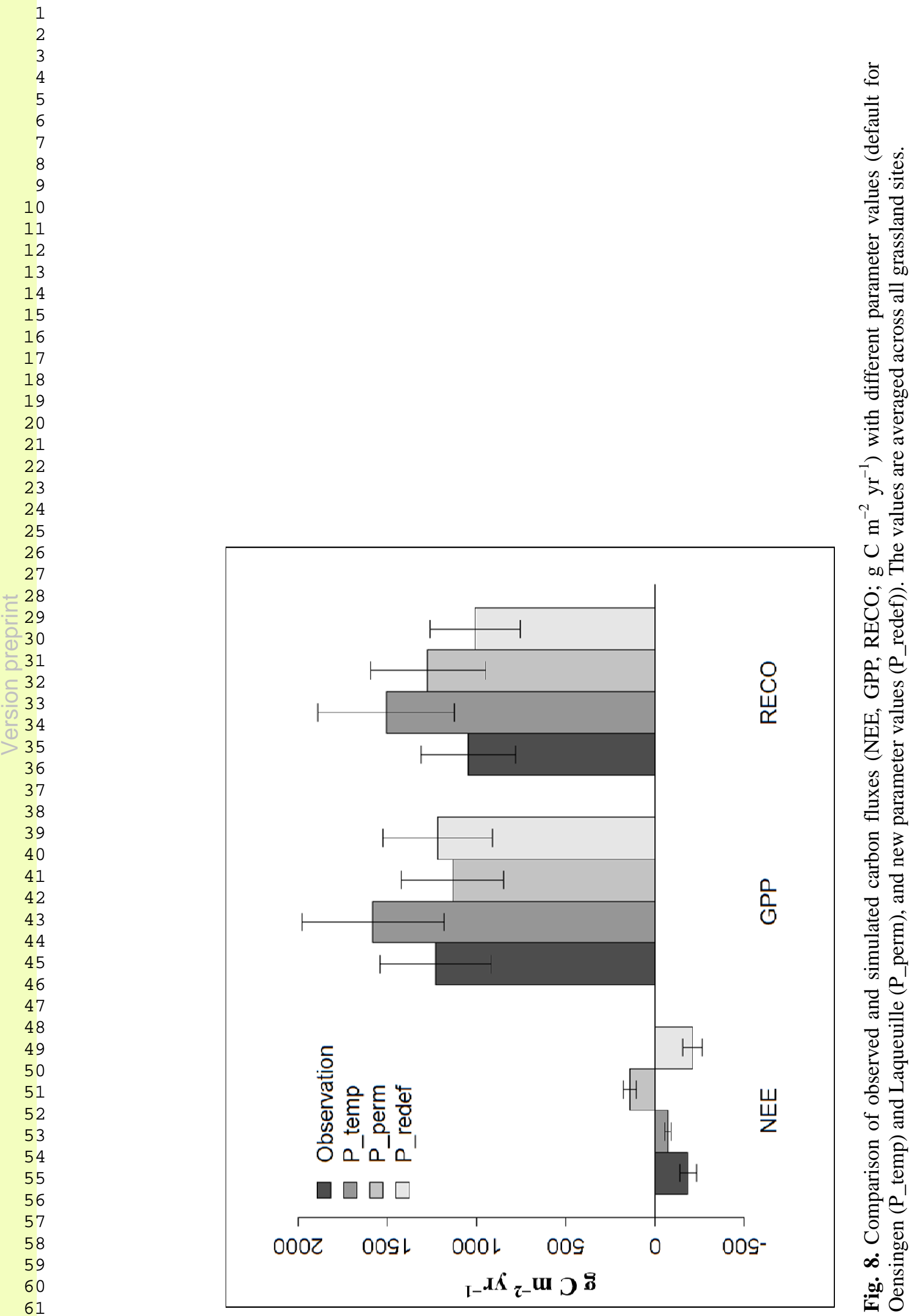




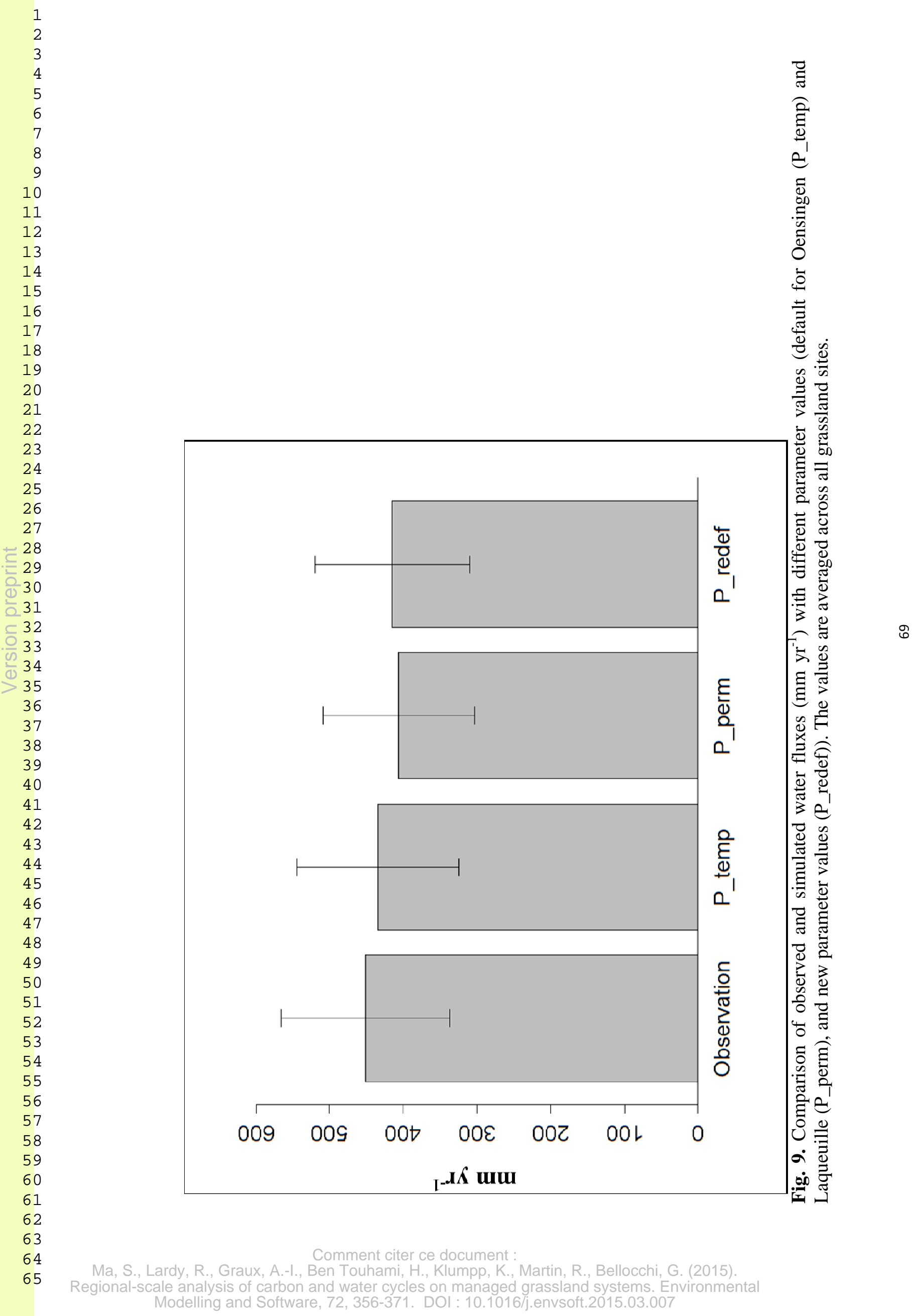



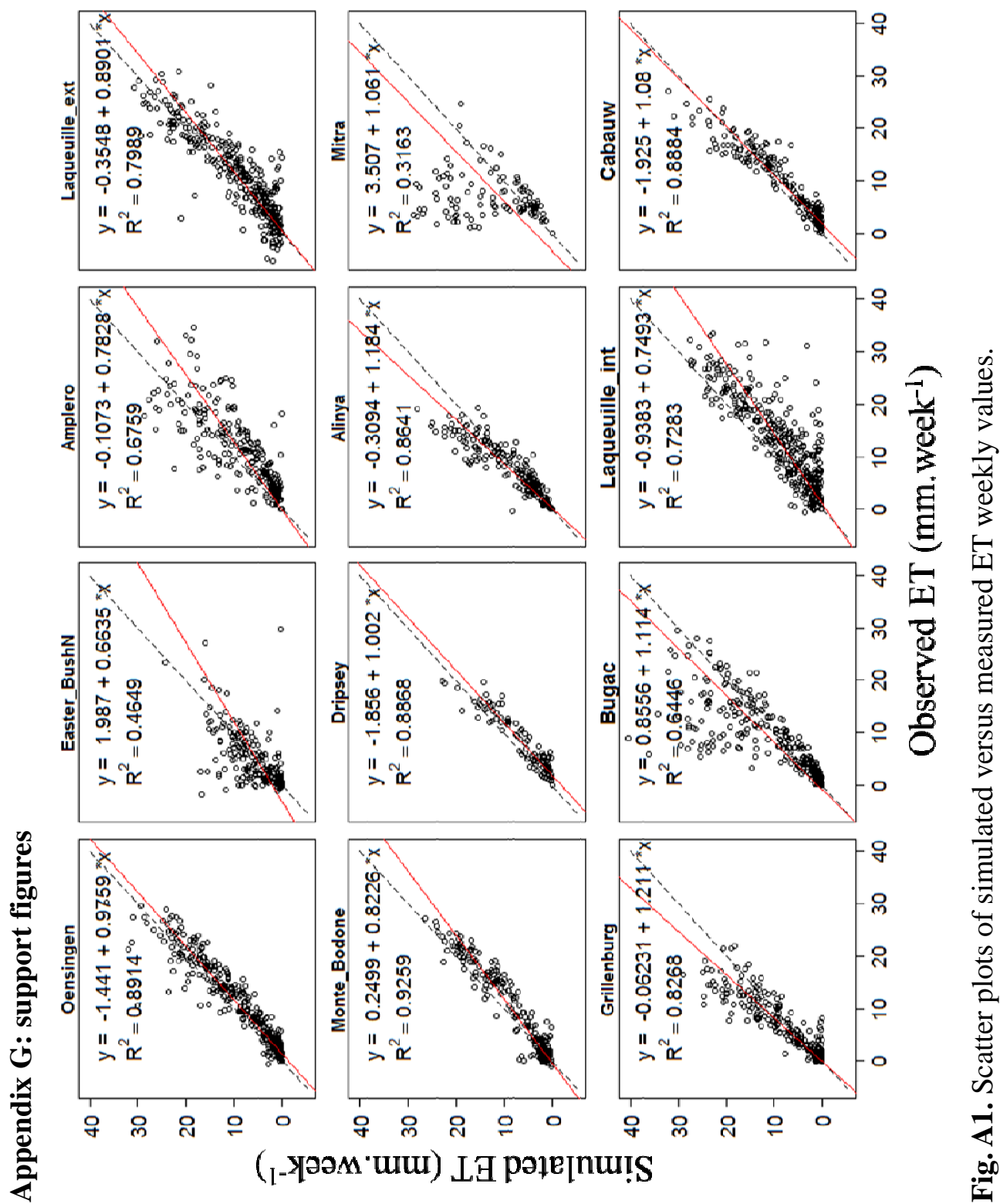

\section{Comment citer ce document}




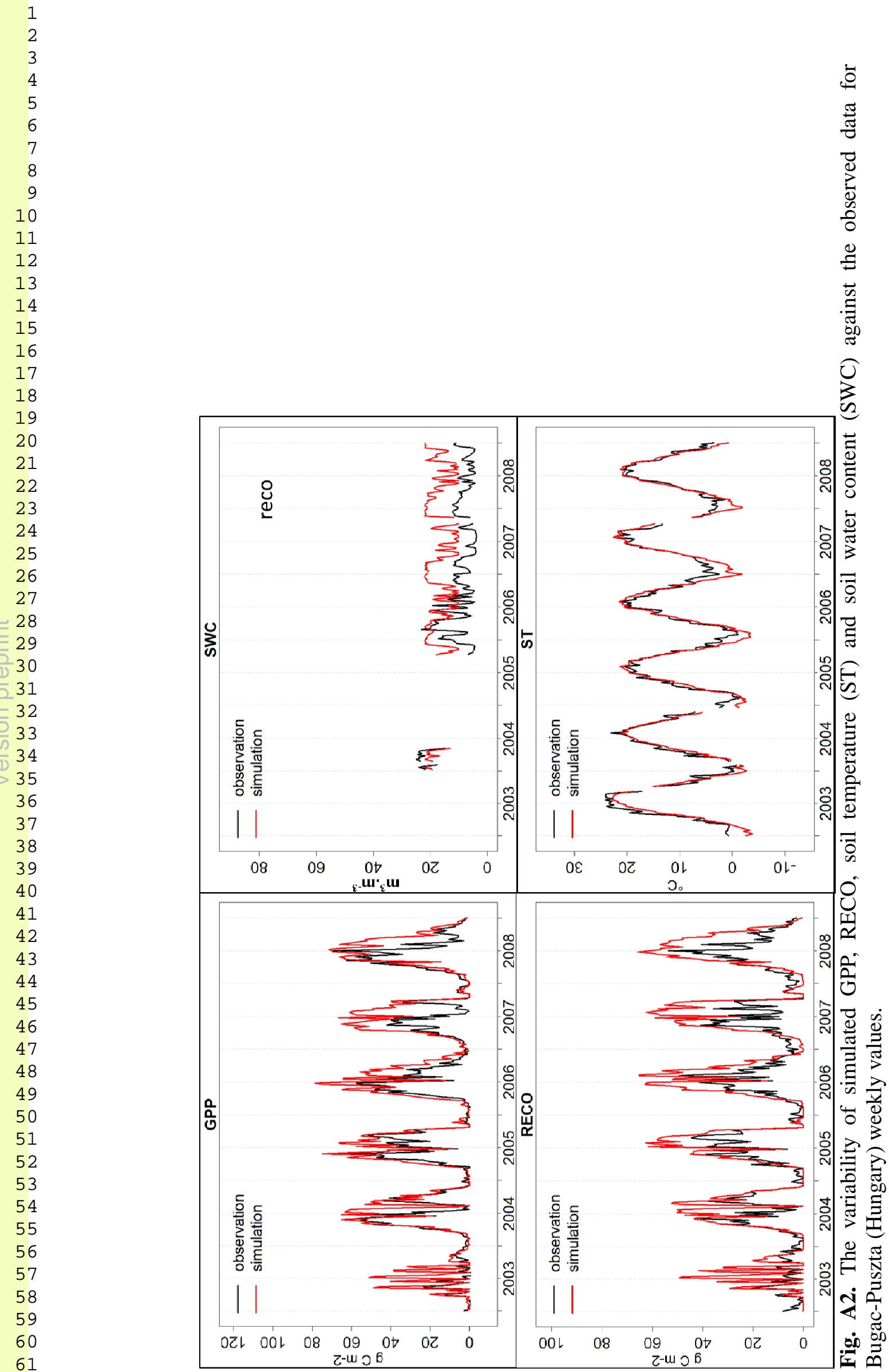




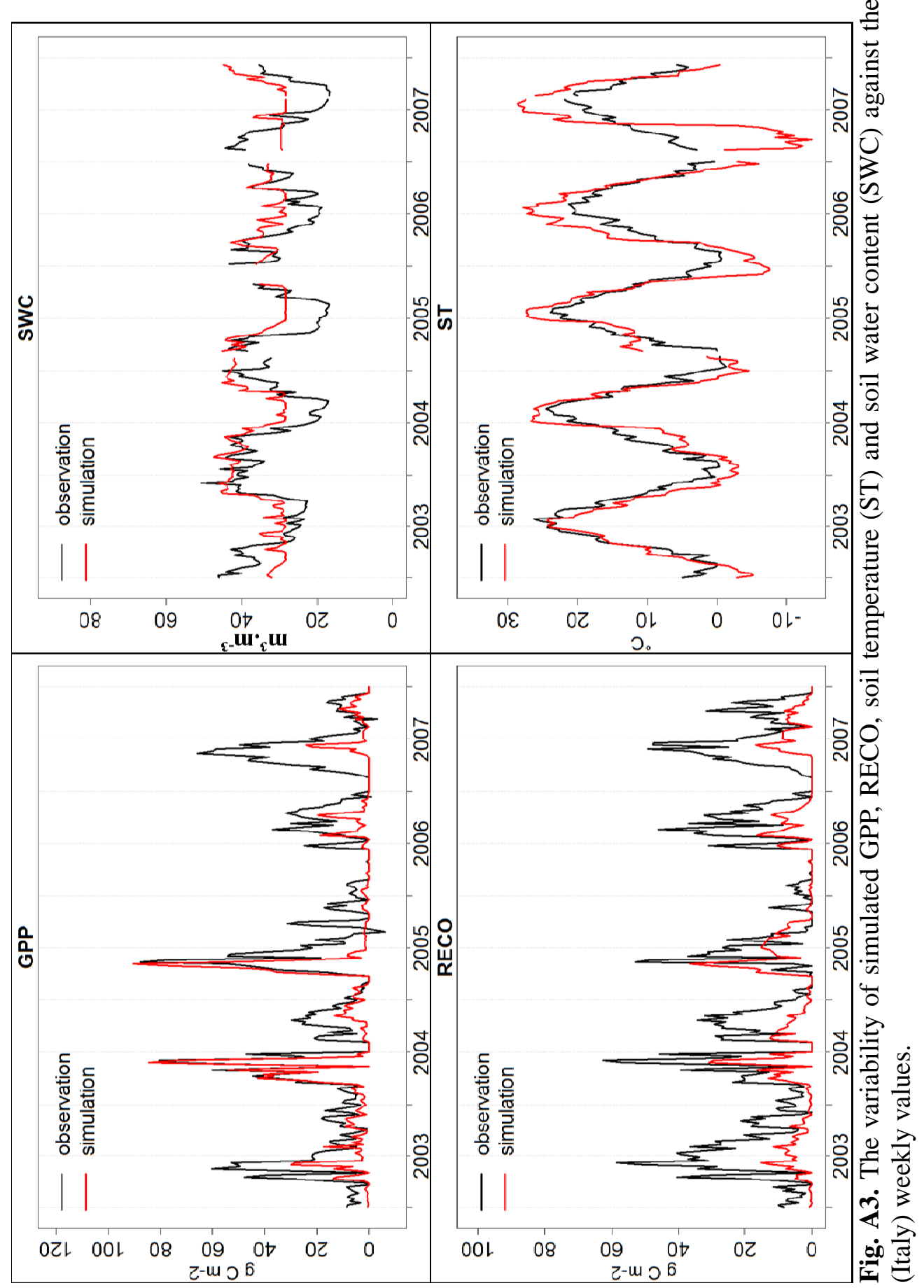

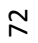




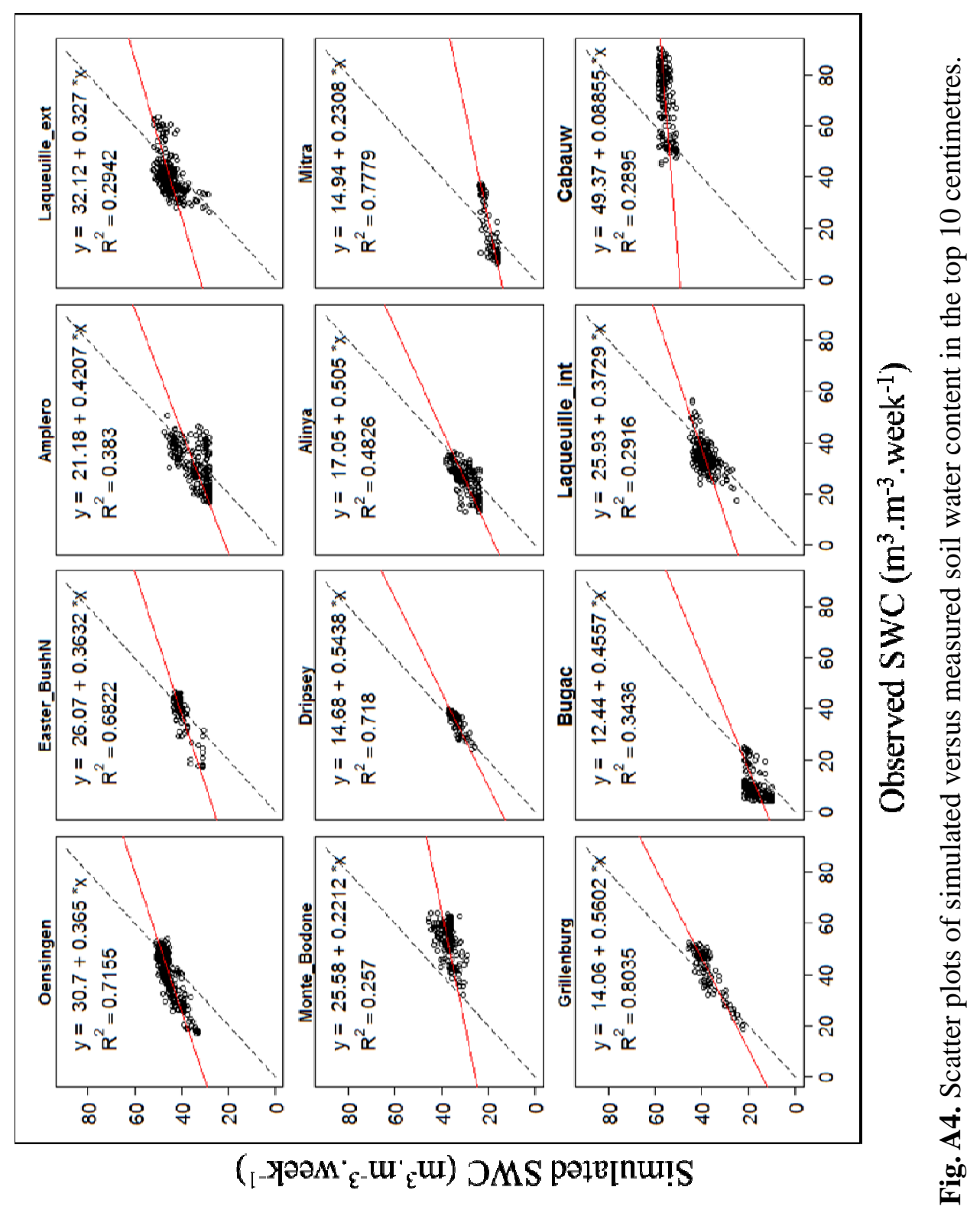




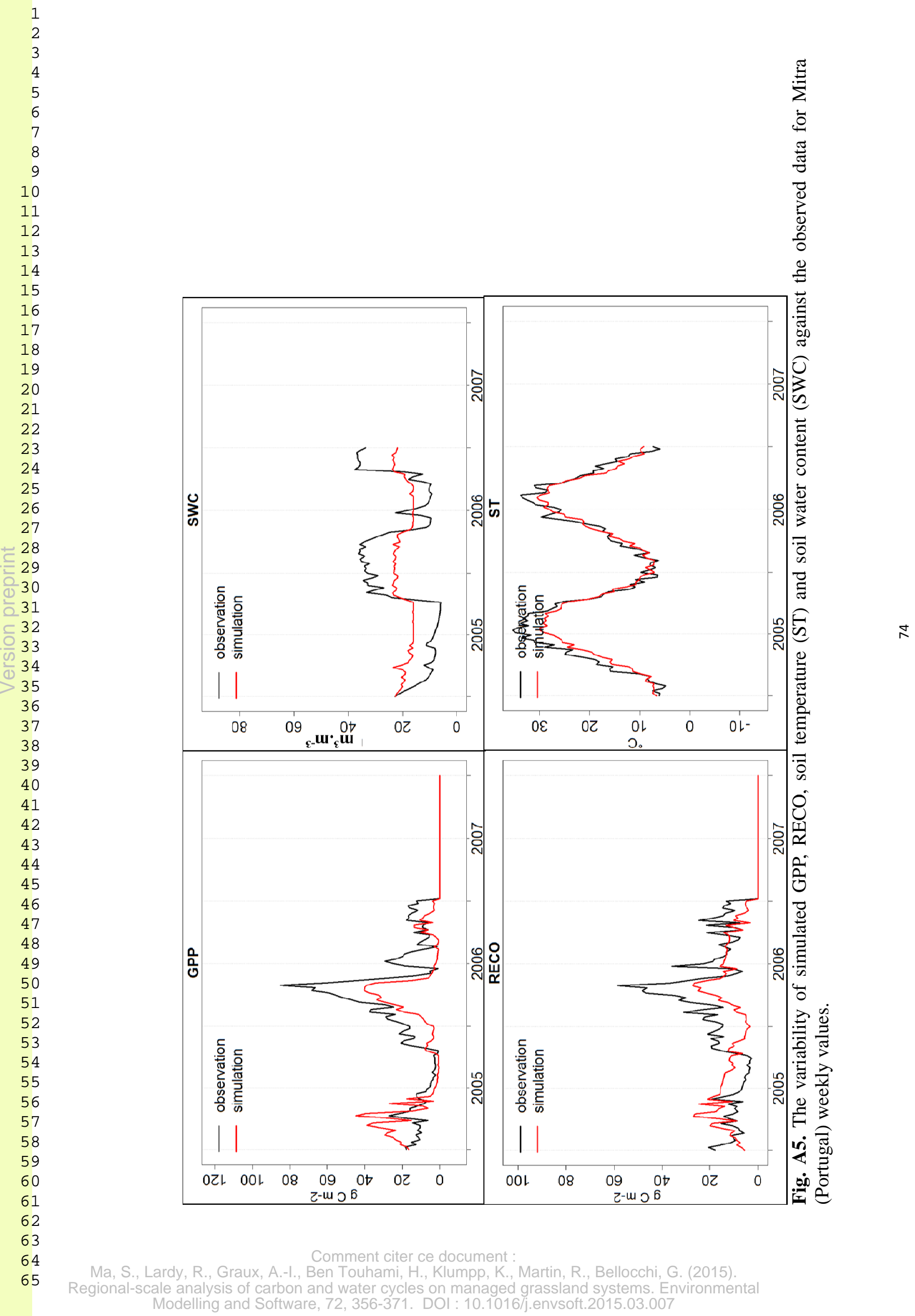


Click here to download Supplementary Material: online_supplementary_material.pptx 
tractable manuscript

Click here to download Supplementary Material: Manuscript-shaoxiuma_03_03_2015_tractable.docx 